Yayınlayan: Ankara Üniversitesi KASAUM

Adres: Kadın Sorunları Araştırma ve Uygulama Merkezi, Cebeci 06590 Ankara

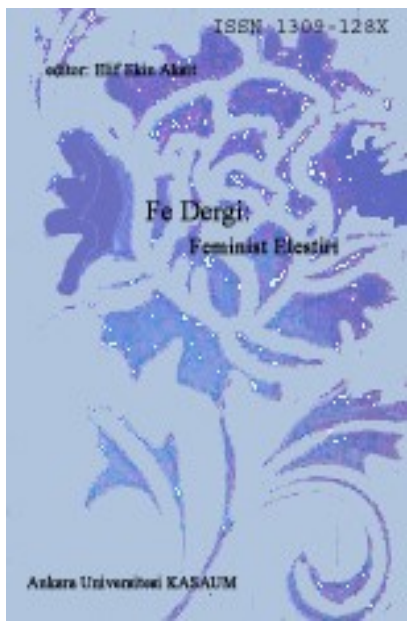

Fe Dergi: Feminist Eleştiri Cilt 6, Sayı 1

Erişim bilgileri, makale sunumu ve ayrıntılar için:

http://cins.ankara.edu.tr/

Sağlıkta Toplumsal Cinsiyet Eşitsizlikleri: Eskişehir'de

Kırsal ve Kentsel Alanlarda Kadın Sağlığı

Temmuz Gönç Şavran

Çevrimiçi yayına başlama tarihi: 2 Haziran 2014

Bu makaleyi alıntılamak için: Temmuz Gönç Şavran, "Sağlıkta Toplumsal Cinsiyet Eşitsizlikleri: Eskişehir'de Kırsal ve Kentsel Alanlarda Kadın Sağlığı,” Fe Dergi 6, no. 1 (2014), 98-116.

URL: http://cins.ankara.edu.tr/11_11.pdf

$\mathrm{Bu}$ eser akademik faaliyetlerde ve referans verilerek kullanılabilir. Hiçbir şekilde izin alınmaksızın çoğaltılamaz. 


\section{Sağlıkta Toplumsal Cinsiyet Eşitsizlikleri: Eskişehir'de Kırsal ve Kentsel Alanlarda Kadın Sağlığı Temmuz Gönç Şavran*}

Toplumsal cinsiyet sağlı̆̆ belirleyen temel faktörlerden biri olarak kabul edilmektedir. Toplumsal cinsiyet hiyerarşisi kadınların ekonomik, sosyal ve politik olanaklara ve güce erişim açısından erkeklere oranla dezavantajlı olduğu bir yapı yaratmakta ve bu dezavantajlar sağlı̆̆a ilişkin risklerin dağılımında, sağlık hizmetlerine erişimde ve sağlık statüsünde görünür hale gelmektedir. Bu çalışmanın amacı, 2009-10 yıllarında Eskişehir'de 229 kişilik bir örneklem üzerinde yürütülmüş olan bir alan araştırmasının bulgularına dayanarak sağlık statüsü, sağlık kurumlarına başvurma ölçütleri, să̆lık riskleri ve să̆lık hizmetlerine yönelik değgerlendirme açllarından kırsal ve kentsel alanlarda yaşayan kadınlarla erkekleri karşılaştırmaktır. Gebelik ve doğumla ilgili konularda da kırsal ve kentsel alanda yaşayan kadınlar karşılaştırılacak, bu veriler üzerinden toplumsal cinsiyet eşitsizlikleri, bölgesel eşitsizlikler ve sağllk eşitsizlikleri arasındaki ilişkiyi irdelenecektir. Bulgular hem kırsal hem de kentsel alanda kadınların sağlıklarının, aynı gelir ve eğitim düzeyine sahip olsalar dahi erkeklere oranla daha kötü olduğunu, ayrıca kırsal alanda yaşayan kadınların să̆lı̆̆ının da kentsel alanda yaşayan kadınlara oranla daha kötü olduğunu göstermektedir. Sonuçlar eğitimsel, ekonomik ve bölgesel gelişmişlikle ilgili eşitsizliklerle sağllk eşitsizliklerinin kesişerek birikimsel bir etki yarattı̆̆ına işaret etmektedir.

Anahtar kelimeler: Sağlık eşitsizlikleri, sosyo-ekonomik statü, kadın sağlı̆̆l, kırsal sağlık, toplumsal cinsiyet

Gender inequalities in health: Women's health in rural and urban areas in Eskișehir

Gender is accepted as a component of social gradient in health. Depending on the disadvantage of women's access to social, economic and political sources, gender stratification become visible in distribution of health risks, access to healthcare and individual health status. Drawing upon a field research conducted in Eskisehir, Turkey in 2009-10 with a sample of 229, the aim of this research is to compare the health risks, healthcare seeking behaviour and health status of men and women in rural and urban areas. The study also aims to compare rural and urban women on issues related to pregnancy and giving birth. The study thus examines the relationship among gender, regional and health inequalities. The findings show that women's health is worse than men in both rural and urban areas, even when men and women share the same educational and income levels. In addition, rural women's health is worse than urban women's. The findings point that gender inequalities intersect with educational, economic and regional inequalities and create a cumulative effect on women.

Keywords: Health inequalities, socio-economic status, women's health, rural health, gender

\section{Giriș}

Sağlık statüsü on dokuzuncu yüzyıl boyunca toplumsal sınıfla ilişkilendirilmiş, 1960 sonrasında toplumsal cinsiyetle ilişkilendirilmeye başlanmış ve 1980 sonrasında da toplumsal cinsiyet sağlığın toplumsal belirleyicilerinden biri olarak kabul edilir hale gelmiştir. ${ }^{1}$ Toplumsal cinsiyet eşitsizlikleri temel olarak kadınların ekonomik ve sosyal kaynaklara ve güce erişim açısından erkeklere oranla dezavantajlı olmasına dayanmakta ve kaynaklara erişimde eşitsizliğe, kamuda yeterince temsil edilmemeye ve erkekler lehine ayrımcı politikalara neden olan bir toplumsal tabakalaşma biçimi yaratmaktadır. ${ }^{2,3} \mathrm{Bu}$ dezavantajlar sağlık alanında sağlığa ilişkin risklerin dağılımında, sağlık hizmetlerine erişimde ve sağlık statüsünde görünür hale gelmektedir. Sürekli olarak sosyal dezavantaja veya ayrımcılığa maruz kalan grupların daha avantajlı sosyal gruplara oranla sistematik olarak daha kötü sağlığa sahip olmalarını ifade eden 'sağlık eşitsizlikleri' ${ }^{4}$ bu noktada toplumsal cinsiyet eşitsizlikleri ile büyük ölçüde kesişmektedir. Kadınların sağlıklarının genel olarak erkeklerinkinden kötü olduğu, ${ }^{5}$ sağlığa bağlı yaşam kalitesi ${ }^{6}$ ve algılanan sağlık statüsü ${ }^{7}$ açılarından erkeklerden daha kötü durumda olduğu

*Yrd. Doç. Dr., Anadolu Üniversitesi Edebiyat Fakültesi Sosyoloji Bölümü 
bilinmektedir. Kadınların kronik ve yaşa bağlı hastalıklara erkeklere oranla daha fazla yakalanmaları sıklıkla küresel olarak kadınların ortalama yaşam sürelerinin erkeklerinkinden uzun olması ile ilişkilendirilmektedir. ${ }^{8,9}$ Bununla birlikte gelişmekte olan ülkelerde ortalama yaşam süresi sabit tutulduğunda bile kadınların sağlıklarının erkeklere oranla daha kötü olduğu bilinmektedir. ${ }^{10}$ Çalışmalar, kadınlarla erkeler arasındaki farklılıkların sadece biyolojik farklılıklardan değil, toplumsal cinsiyet hiyerarşisinden ve toplumsal cinsiyete dayalı rollerin yarattığı psiko-sosyal stresten de kaynakladığın $1^{11,12}$ ve toplumsal belirleyicilerin biyolojik korunmasızlığı pekiştirdiğini ${ }^{13}$ göstermektedir.

Toplumsal cinsiyetin bireylerin sağlık hizmetlerinden yararlanma ve sağlık düzeylerini etkileyen faktörlerden biri olması ${ }^{14}$ toplumsal cinsiyet eşitsizliklerinin sağlık alanına yansımasının bir sonucudur. Bireylerin sağlık hizmetlerinden yararlanma düzeylerini belirleyen başlıca faktörler arasında istihdam statüsü, gelir ve eğitim düzeyi, ekonomik kaynaklar üzerinde kontrol düzeyi, tıbbi bakımın ulaşılabilirlik düzeyi, sigorta kapsamına girip girmeme, sağlık beklentileri, yardım alma davranışında başkalarının rolleri, cinsiyete dayalı rol ve etkinlikler ve karar verme gücü düzeyi sayılmaktadır. ${ }^{15}$ Ancak bu faktörlerin etkisi toplumsal cinsiyetten bağımsız değildir. Nitekim yapılan çalışmalar erkeklerin kendi aralarındaki sağlık statüsü farklılıklarının açıklanmasında meslek ve istihdam statüsü gibi ekonomik faktörlerin ailevi rol ve sorumluluklardan daha önemli olduğunu $^{16}$ ancak kadınlar için cinsiyete dayalı rollerin de en az ekonomik etkenler kadar önemli olduğunu ${ }^{17}$ göstermektedir. Her ne kadar gelişmiş ülkelerde kadın hastalıkları ve doğumla ilgili servislerdeki muayeneler çıkarıldıktan sonra bile kadınların sağlık bakımı kurumlarına erkeklerden daha sık başvurdukları ortaya konmuş olsa $\mathrm{da}^{18}$ bu durum kadınların erkeklere oranla hastalık oranlarının yüksek olmasından kaynaklanmakta ve oranlar bütün ülkelerde benzer seyretmemektedir. Örneğin sağlık hizmetlerinin cepten yapılan harcamalara dayandığı ve azgelişmiş ülkelerde kadınlar sağlık hizmetlerine erkeklerden daha az erişmektedirler. ${ }^{19} \mathrm{Bu}$ düşük erişim düzeyi bir yandan hanenin ekonomik kaynaklarına kısıtlı erişimden, diğer yandan bazı gelişmekte olan ülkelerde kadınların toplu taşıma araçlarına tek başına binmelerinin yasak olması ${ }^{20}$ ya da kadınların muayene olmak ya da tedavi görmek için hanelerindeki erkeklerden izin almalarının gerekmesi ${ }^{21}$ gibi cinsiyetçi engellerden kaynaklanmaktadır.

Hem ekonomik kaynaklara erişimdeki eşitsizlikler hem de kadınların fiziksel hareketliliğini kısıtlayan sosyal ve kültürel zorunluluklar nedeniyle kadınların kendi kendilerini tedavi etme, vasıfsız kişilerden sağlık hizmeti alma ve lisanssız ilaç kullanma oranlarının erkeklerinkinden yüksek olmasına neden olduğu belirtilmektedir. ${ }^{22}$ Kadınların sağlık hizmetlerine erişimi sağlansa bile sağlık hizmeti verenler cinsiyetçi algılara sahip olabilmekte, bu algı tedavi sürecinde erkek hastalara oranla kadın hastaların daha az ilgi ve özen görmelerine ve daha düşük düzeyde bilgilendirilmelerine neden olabilmektedir. ${ }^{23}$ Kurumsal tıbbın kadınları dinlemeye ve onlara açıklama yapmaya zaman ayırmaması, kadınların erkeklere oranla geleneksel tedavileri daha çok kullanmalarının nedenlerinden biri olarak görülmektedir. ${ }^{24}$

Türkiye'de geleneksel ataerkil yaşam biçimi bölgesel olarak ve kısmen çözülmeye başlamış olsa da halen toplumsal cinsiyet eşitsizliklerinin yaratılmasına katkıda bulunmakta, kadınların erkeklere oranla düşük olan toplumsal statülerini yeniden üretmekte ve sağlık hizmetlerine erişimini engellemektedir. ${ }^{25}$ Sağllkta Dönüşüm Programı çerçevesinde uygulamaya konan Genel Sağlık Sigortası ile birlikte nüfusun daha büyük bir kısmı sağlık sigortası kapsamına alınmış olsa da sistemin prime dayalı olması, prim borcunun sağlık hizmeti almayı engellemesi ve prime ek olarak yapılması gereken katkı ve katılım payı ödemeleri kadınların sağlık hizmeti almalarını zorlaştırmaktadır. ${ }^{26}$ Çalışmalar Türkiye'de azgelişmiş bölgelerde ve kırsal alanda yaşayanların, işsizlerin, en düşük gelir diliminde bulunanların ve kadınların daha fazla cepten sağlık harcaması yaptığını göstermektedir. ${ }^{27}$

Türkiye'de kadının statüsüne genel olarak bakıldığında eğitim, istihdam ve sağlık statüsü açısından erkeklerden daha kötü durumda oldukları görülmektedir. 2011 yılı itibariyle Türkiye'de 15 yaş üzerinde okuma yazma bilmeyenlerin \%83'ü kadındır ve 2012 itibariyle erkeklerin \%72'si, kadınların ise ancak \%30'u işgücüne katılabilmektedir. ${ }^{28} \mathrm{Bu}$ veriler sağlığın eğitim ve istihdamla ilişkisi ışı̆̆ında dikkate alındığında, Türkiye'de kadınların sağlıklarını olumsuz etkileyecek risklere erkeklere oranla daha fazla maruz kaldıklarına dair bulgular ${ }^{29}$ şaşırtıcı değildir. Bu durum kadınların algılanan sağlık statülerinin erkeklerden daha kötü olmasına neden olmakta, resmi verilere göre 2012 yılı itibariyle erkeklerin dörtte üçünden fazlası (\%77) sağlığını iyi veya çok iyi olarak değerlendirirken bu oran kadınlarda \%64'de kalmaktadır. ${ }^{30}$ Toplumsal cinsiyete dayalı eşitsizliklere bölgesel eşitsizlikler eklendiğinde kırsal alanda yaşayan kadınların sağlık alanındaki dezavantajları derinleşmektedir. Kırsal alanda yaşayan kadınların sağlıklarının kentsel alanda yaşayanlara oranla daha kötü olduğunu gösteren çalışmalara ${ }^{31}$ paralel olarak Türkiye'de de kentsel alanda yaşayan erkeklerin \%80'i, kadınların 
ise \%70'i sağlığını iyi olarak algılarken bu oranlar kırsal alanda erkeklerde \%68'e, kadınlarda \%57'ye gerilemektedir. ${ }^{32}$ Türkiye'de kadınların formel sağlık hizmetlerinden yararlanmasında özellikle eğitim düzeyi, yaşanan yer (kır/kent) ve bölge (doğu/batı) belirleyicidir. ${ }^{33}$ Örneğin kırsal alanda yaşayan, eğitim ve gelir düzeyi düşük olan kadınların doğum öncesi en az bir kere sağlık personelinden bakım alma ve doğumları sağlık kuruluşlarında gerçekleştirme oranları, Türkiye ortalamasının altındadır. ${ }^{34}$

Bu çalışmanın amacı, Eskişehir'de yapılan bir araştırmanın verileri üzerinden bir yandan kırsal ve kentsel alanlarda yaşayan düşük statü gruplarında kadınlarla erkekleri karşılaştırarak toplumsal cinsiyet eşitsizlikleri ile sağlık eşitsizlikleri arasındaki ilişkiyi incelemek, bir yandan da kırsal ve kentsel alanda yaşayan kadınları karşılaştırarak sağlık eşitsizliklerinin birikimsel desenini ortaya koymaktır. Diğer bir deyişle tüm toplumun sağlı̆̆ını belirleyen yapısal faktörler dışında ataerkil sistemin normlarından kaynaklanan ve kadın sağlığını etkileyen faktörler olup olmadığının değerlendirilmesi amaçlanmaktadır. Çalışma ayrıca kırsal ve kentsel alanda yaşayan kadınların verilerini karşılaştırarak bölgesel eşitsizliklerle cinsiyet eşitsizliklerinin nasıl kesiştiğini incelemeyi amaçlamaktadır.

\section{Yöntem}

Bu çalışma, 2009-10 yıllarında Eskişehir'de yürütülmüş olan nicel bir alan araştırmasının bulgularına dayanmaktadır. ${ }^{35}$ Araştırma evrenini Eskişehir'de yaşayan kırsal ve kentsel düşük statü grupları oluşturmaktadır. Araştırmanın amacı kırsal ve kentsel alanın ayrıştığı ve benzeştiği noktaları ortaya koymayı gerektirdiği için örneklem, kırsal ve kentsel düşük statü gruplarını temsil ettiği varsayılan bölgelerden kota örnekleme tekniği ile seçilmiştir.

Bu çerçevede Eskişehir'de kırsal alanın dezavantajlarını yansıtması amacıyla en az gelişmiş iki ilçenin en yüksek nüfuslu köyleri araştırmaya dahil edilmiştir. Eskişehir'in en az gelişmiş ilçeleri Türkiye'de bulunan toplam 872 ilçe içinde insani gelişmişlik endeksine göre 619. Sırada olan Han ve 591. sirada yer alan Günyüzü' dür. ${ }^{36}$ Han ilçesi, Eskişehir'in güneyinde bulunan, 2008 itibariyle 2,488 nüfuslu, 335 km² yüzölçümüne sahip olan bir ilçedir ve nüfusunun yaklaşık yarısı (1,222 kişi) belde ve köylerde yaşamaktadır. ${ }^{37} 2004$ yılı itibariyle şehirleşme oranı \%55,69 olan Han'da nüfus artış hızı binde $-0,55$, nüfus yoğunluğu 15 , ortalama hane büyüklüğü 4,50'dir. Han nüfusunun \% 78,37'si tarım sektöründe çalışmaktadır. İşsizlik oranı \% 5,85, okuryazarlık oranı \%81,63, bebek ölüm oranı binde 48,19, nüfus bağımlılık oranı \%58,14'tür. ${ }^{38}$ 2007-2008 yılları arasında Han ilçesinin nüfus artış oranı -1,50'dir. ${ }^{36}$ Han ilçesinden seçilen köylerden biri olan Kayı Köyü, 2008 itibarıyla 382 nüfusa sahip olan, ilçe merkezine $17 \mathrm{~km}$., Eskișehir il merkezine $100 \mathrm{~km}$. uzaklıkta bulunan bir köydür. Köyde sağlık ocağı yoktur, sağlık evi vardır ancak faal değildir. İlköğretim okulu vardır ve faaliyettedir. Su şebekesi ve kanalizasyon (foseptik çukurlarına bağlı) vardır. Köye gezici sağlık taraması en son 2 yıl önce gelmiştir. 40 hanenin 10-15'inde tarım makinesi olmakla birlikte yakıt ücreti yüksek olduğu için makineler çoğunlukla kullanılmamaktadır. Köye Han ilçesinden haftada bir doktor ziyareti yapılmaktadır. Yine Han ilçesine bağlı olan Gökçeyayla Köyü ise Han ilçe merkezine 16 km., Eskişehir il merkezine $121 \mathrm{~km}$. uzaklıkta yer alan, sağlık ocağı ve sağlık evi olmayan, su ve kanalizasyon şebekesi bulunmayan, ilköğretim okulu olmayan bir köydür. Resmi kayıtlara göre nüfusu 147'dir, ancak muhtarlık veri toplanan dönemde nüfusun 83 olduğunu bildirmiştir. Günyüzü ilçesi ise Eskişehir'in güneybatısında bulunan, 2008 itibariyle 7,678 nüfuslu, $789 \mathrm{~km}^{2}$ yüzölçümüne sahip olan bir ilçedir ve nüfusunun yaklaşık \%70’i (5,366 kişi) belde ve köylerde yaşamaktadır. ${ }^{36}$ Günyüzü'nde 2004 itibariyle şehirleşme oranı \%28,70, nüfus artış hızı binde 11,71, nüfus yoğunluğu 12, ortalama hane büyüklüğü 5,10'dur. Nüfusun \%85,4'ünün tarım sektöründe çalıştığı ilçede işsizlik oranı \%5,39, okuryazarlık oranı \%92,52, bebek ölüm oranı binde 14,18, nüfus bağımlılık oranı \%61,63'tür. ${ }^{37}$ 2007-2008 yılları arasında Günyüzü ilçesinin nüfus artış oranı -5,62' dir. ${ }^{36}$ Ayvalı Köyü, Günyüzü ilçesine bağlı olan, 2008 itibariyle 564 nüfuslu bir köydür. Ayvalı Köyü'nde 480 hane bulunmaktadır. Köyde yaşayanların büyük kısmını 1955 yılında Eskişehir'e göç etmiş olan göçmenler oluşturmaktadır. Köydeki hanelerin \%70'inde traktör gibi tarım makineleri vardır ancak diğer köylerde olduğu gibi yakıt ücretlerinin yüksekliği nedeniyle çoğunlukla kullanılmamaktadır. Köyde sağlık ocağı yoktur, ancak faal bir sağlık evi vardır. İlköğretim okulu faaldir. Sağlık evinde sağlık meslek lisesinden mezun olmuş bir ebe-hemşire görev yapmaktadır. Doktor gereksinimlerini genellikle yakın mesafedeki Gümüşkonak Kasabası'na giderek karşılamaktadırlar. Ayvalı Köyü’nde su şebekesi olmakla birlikte şebekenin kaynağı yazın kuruduğu için yazları yaklaşık üç ay boyunca köy susuz kalmaktadır. Köy muhtarı, yapılan incelemelerde kaynağın suyunun içme suyu olarak kullanılmaması gerektiğinin ortaya çıktığını ve bu yönde rapor düzenlendiğini belirtmektedir, ancak yine de köyde bu kaynağın suyunu içme suyu olarak kullananlar mevcuttur. Kanalizasyon şebekesinin foseptik çukurlarına bağlı olduğu Ayvalı Köyü’ndeki 
ebenin beyanına göre yazın su akmadığı dönemlerde başta ishal ve kadın hastalıkları olmak üzere çeşitli hastalıklarda artış gözlenmektedir.

Kentsel düşük statülü nüfusu temsil etmek üzere Eskişehir'de ağırlıklı olarak düşük statü gruplarının yerleştiği Emek ve Gündoğdu mahalleleri araştırmaya dahil edilmiştir. Eskişehir kent merkezindeki mahallelerde oturan örneklemin \%48,4'ü Gündoğdu, \%51,6'sı Emek mahallesinde yaşamaktadır. Muhtarlıktan alınan bilgilere göre 2010 itibariyle Gündoğdu Mahallesi 3000 haneli, 9239 erkek 8796 kadın olmak üzere resmi kayıtlara göre 18,000 nüfuslu bir mahalledir. Mahalle muhtarlığından alınan bilgilere göre Emek Mahallesi resmi rakamlara (ikametgâh bilgilerine) göre 15,000 haneli ve 30,000 nüfuslu bir mahalledir.

Örnekleme seçilen köyler Eskişehir'in kırsal alanını temsil etmemektedir, bu açıdan bulgular ancak kırsal alanın dezavantajlarına sahip düşük statülü kırsal nüfus için geçerli olacaktır. Kent merkezinde seçilen mahalleler de kentsel düşük statülü nüfusu temsil etmek üzere seçilmişlerdir. Sosyal ve ekonomik statüyü belirlerken temel olarak yaşanan yerin niteliği, gelir, eğitim ve meslek değişkenleri dikkate alınmıştır ve düşük statülü nüfus ile kastedilen, eğitim, gelir, meslek ve istihdam statüsü açısından dezavantajlı olan, kendi içinde homojen olan ve büyük ölçüde ortak bir yaşam tarzını paylaşan nüfustur. Bu açıdan kentsel düşük statünün tipik örneğini elde edebilmek amacıyla kentsel alanın avantajlarından faydalanamayan derin yoksulların yoğunlaştığı ve kentin saçaklarında yer alan mahalleler değil, ağırlıklı olarak endüstriyel alanda istihdam edilenlerin yaşadığı ve kent merkezine yakın mahalleler seçilmiştir.

Kırsal örneklem, seçilen köylerde yaşayan 1029 kişi içinden kota örnekleme ile seçilen 103 (54 erkek, 49 kadın) kişiden oluşmaktadır. Bu grup seçildikten sonra karşılaştırma yapmak amacıyla Emek ve Gündoğdu mahallelerinde yaşayan yaklaşık aynı büyüklükte bir grup (126 kişi, 66 erkek, 60 kadın) yine kota örnekleme ile seçilmiş ve toplamda 229 kişilik bir örneklemden veri toplanmıştır. Böylece hem kırsal ve kentsel alanlarda yaşayan düşük statülü kadınlarla erkeklerin verilerini, hem de kırsal alanda ve kentsel alanda yaşayan düşük statülü kadınların verilerini karşılaştırmak mümkün olmuştur. Statü gruplarından kaynaklanan eşitsizlik ve farklılıkların cinsiyete dayalı eşitsizlik göstergelerini etkilememesi için örneklemdeki kadın ve erkeklere ilişkin veriler kendi statü grupları içinde karşılaştırılmış, ayrıca cinsiyete dayalı eşitsizliklerle bölgesel eşitsizliklerin nasıl kesiştiğini incelemek amacıyla kırsal ve kentsel kadınlar kendi aralarında karşılaştırılmıştır.

Örnekleme girenlerin tamamı ile yüz yüze yapılandırılmış görüşmeler yapılmıştır. Görüşmeler sırasında kullanılan soru formları, yaklaşık üçte biri açık uçlu olan 78 sorudan oluşmaktadır. Açık uçlu sorulara verilen cevaplar kendi içlerinde gösterdikleri kümelenme doğrultusunda kategorileştirilerek analiz edilmek üzere SPSS'e aktarılmıştır. Genel sağlık statüsünü ölçmek amacıyla MOS 36 Öğeli Sağlık Taraması Kısa Formundan ve D. Goldberg ve P. Williams tarafından geliştirilen Genel Sağlık Anketinden ${ }^{39}$ (GHQ-28) yararlanılarak bir ölçek hazırlanmıştır. Yapılan çalışmalar MOS 36 ölçeğinin güvenirliğinin 0,65-0,94 arasında değiştiğini ve Genel Sağlık Anketi'nin güvenirliğinin 0,70 olarak gözlendiğini göstermektedir. ${ }^{40} \mathrm{Bu}$ araştırmanın verileri ile yapılan güvenirlik testine göre çalışmada kullanılan ölçeğin güvenirliği 0,57 'dir. Sağlık statüsü, bu ölçekte yer alan kronik hastalık sayısı, hastalanma, yorgun hissetme, ağrılı hissetme, ilaç içme, uyku bozukluğu yaşama ve stresli hissetme sıklığı değişkenlerinin sayısal toplamıyla elde edilen bir değişkenle ölçülmüştür.

Örneklemin genel sosyal ve demografik özellikleri Tablo 1'de görülmektedir. Eğitim ve gelir düzeyi en düşük olanlar kırsal alanda yaşayan kadınlardır, onları kırsal alanda yaşayan erkekler izlemektedir. Kentsel alanda yaşayan kadınların gelir ve eğitim düzeyleri kentsel alanda yaşayan erkeklerden düşük olmakla birlikte kırsal alanda yaşayan kadınlardan yüksektir.

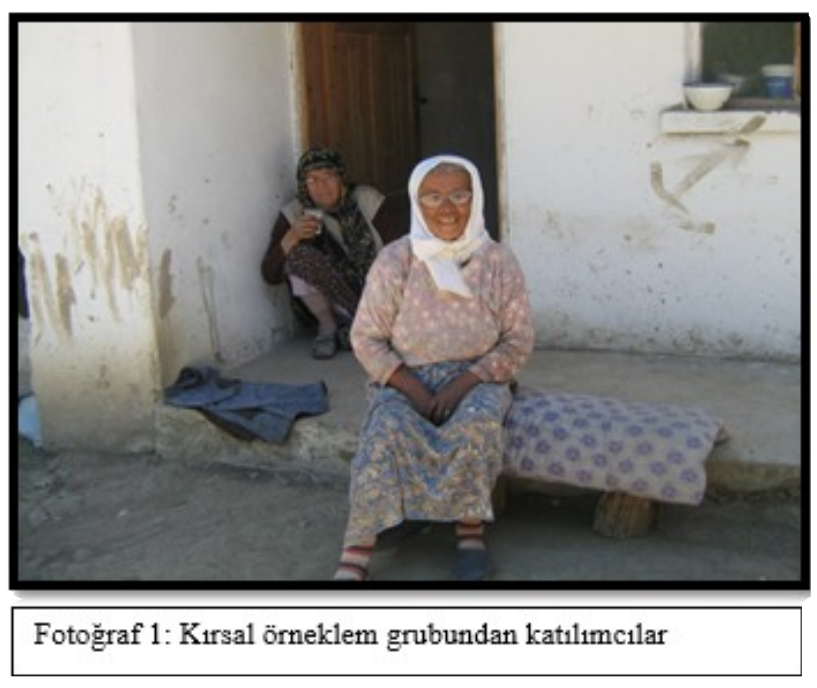


Tablo 1: Örneklemin sosyal ve demografik özellikleri

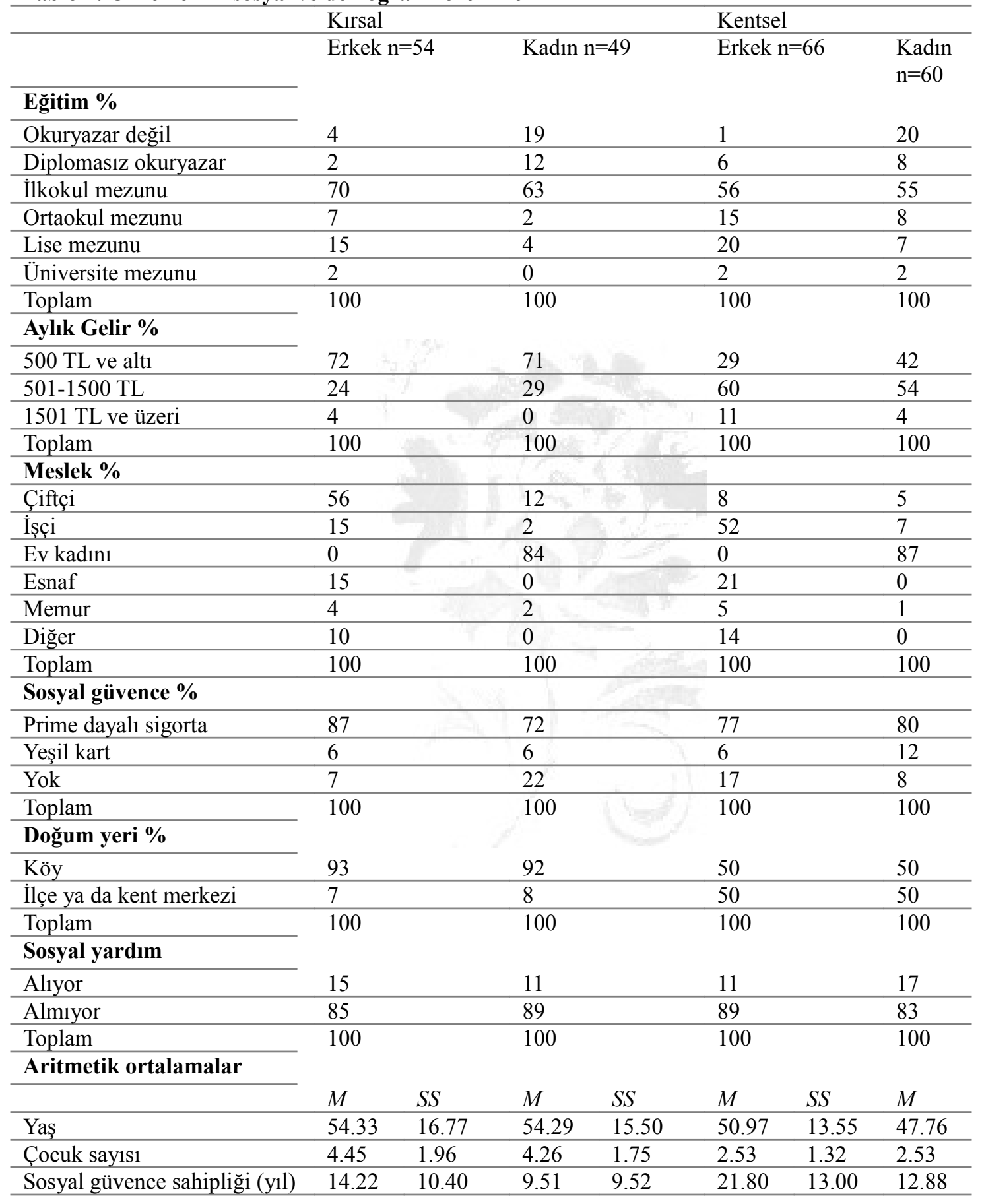




\section{Bulgular}

\section{Să̆lık statüsü}

Bulgular kadınların sağlığının erkeklere oranla daha kötü olduğunu göstermektedir. En fazla kronik hastalığa sahip olanlar kırsal alanda yaşayan kadınlardır (ortalama 2.47; SS=1.70), onları kentsel alanda yaşayan kadınlar (2.33; SS=1.66) izlemektedir. Kırsal alanda yaşayan erkeklerin kronik hastalık sayısı ortalaması (1.67; SS=1.61) kentsel alanda yaşayan erkeklere (1.15; SS=1.61) oranla daha yüksektir. Genel sağlık statüsü incelendiğinde hem kırsal hem de kentsel alanda yaşayan kadınların neredeyse yarısına yakınının sağlığının kötü olduğu, erkeklerde ise bu oranın çok daha düşük düzeyde kaldığı görülmektedir. Buna paralel olarak erkekler kadınlara oranla, kentsel alanda yaşayan kadınlar da kırsal alanda yaşayan kadınlara göre sağlıklarını daha 'iyi' algılamaktadırlar. $\mathrm{Bu}$ bulgular kadınların kronik hastalıklara erkeklere oranla daha fazla yakalandıklarını, ${ }^{41,42}$ sağlıklarının da ${ }^{5}$ algılanan sağlık statülerinin de ${ }^{43}$ erkeklerden daha kötü olduğunu gösteren çalışmalarla paraleldir.

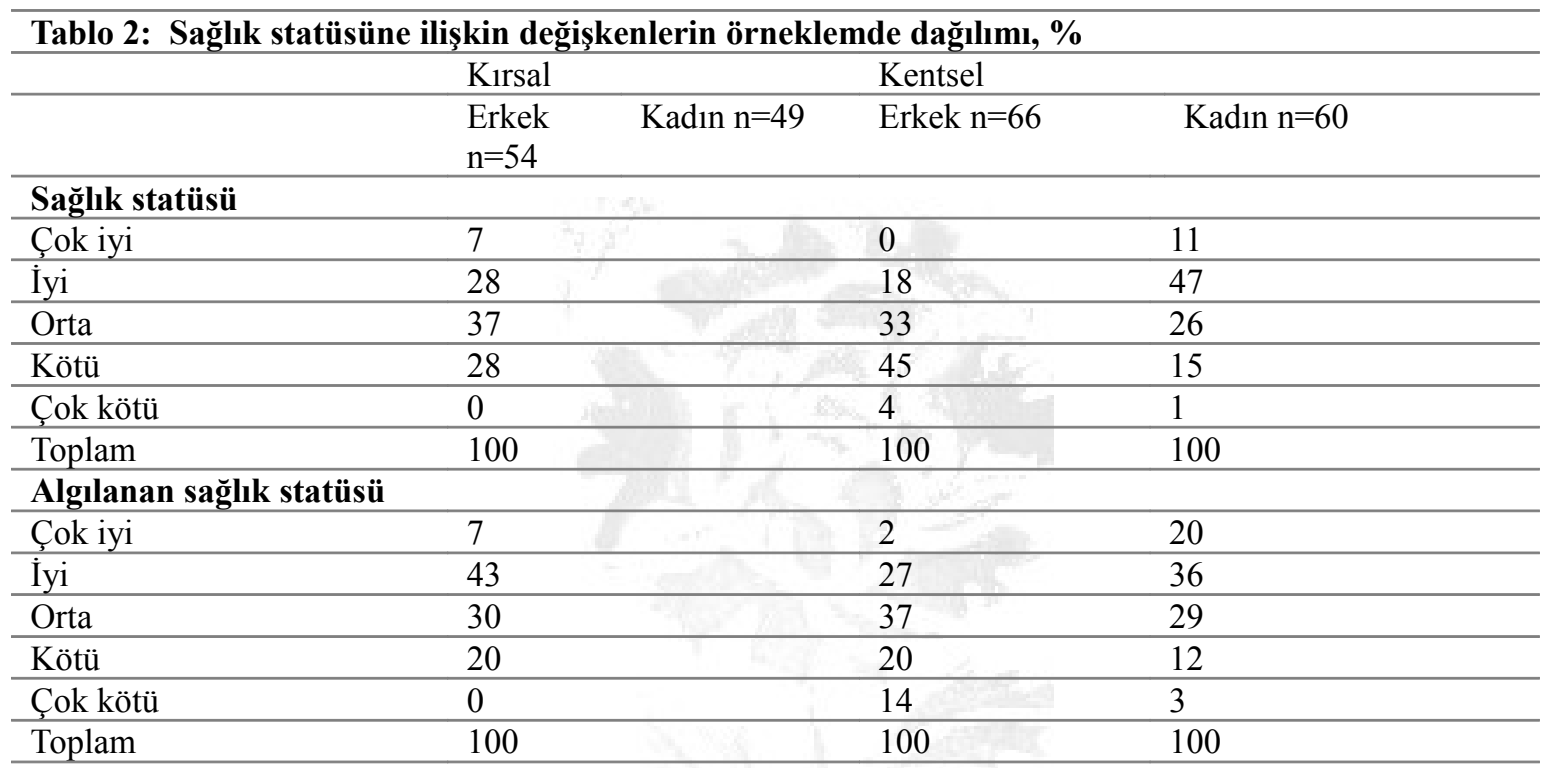

Kadınların da erkeklerin de sağlık statüleri gelir ve eğitim düzeyi ile doğru orantılıdır, diğer bir deyişle gelir ve eğitim düzeyi daha yüksek olanlar daha düşük olanlara oranla daha sağlıklıdırlar. Ancak eğitim ve gelir kategorileri kendi içinde incelendiğinde, kadınların sağlık statüleri, kendileriyle aynı eğitim ve gelir düzeyine sahip olan erkeklerden daha kötüdür. Tablo 3'te görülebileceği gibi eğitim ve gelir değişkenlerinin neredeyse bütün kategorilerinde kadınların sağlıklarının iyi olma oranları erkeklerden düşük, kötü olma oranları da erkeklerden yüksektir. Bu bulgular, ekonomik faktörlerin erkeklerin sağlık statüsünü kadınlara oranla daha fazla etkilediğini gösteren çalışmaları ${ }^{21,38}$ desteklemektedir. Bu durum göstermektedir ki kadın sağlığı, eğitim ve gelir gibi sağlık statüsünü doğrudan etkilediği bilinen temel faktörlerin dışında, toplumsal cinsiyete dayalı sosyal k1sitlılıklardan da etkilenmektedirler.

\begin{tabular}{llllllll}
\hline \multicolumn{7}{l}{ Tablo 3: Kadın ve erkeklerin sağlık statülerinin gelir ve eğitime göre dağılımı, $\%$} \\
\hline & Erkek & $\mathrm{n}=120$ & & & Kadın & $\mathbf{n = 1 0 9}$ \\
\hline & Iyi & Orta & Kötü & Toplam & İyi & Orta & Kötü \\
\hline Eğitim düzeyi (diploma) & & & & & & & \\
\hline Diplomasız & - & 71 & 29 & 100 & 3 & 41 & 56 \\
\hline Ilkokul & 33 & 38 & 29 & 100 & 3 & 52 & 45 \\
\hline Ortaokul & 29 & 57 & 14 & 100 & 17 & 33 & 50
\end{tabular}


103

\begin{tabular}{llllllll}
\hline Lise ve üzeri & 39 & 61 & - & 100 & 14 & 71 & 15 \\
\hline Aylık gelir düzeyi & & & & & & & \\
\hline 500 TL ve altı & 20 & 55 & 25 & 100 & 3 & 51 & 46 \\
\hline $501-1000$ TL & 33 & 43 & 24 & 100 & 6 & 41 & 53 \\
\hline $1001-1500$ TL & 56 & 33 & 11 & 100 & 12 & 50 & 38 \\
\hline 1501 TL ve üzeri & 87 & 13 & - & 100 & - & 100 & - \\
\hline
\end{tabular}

\section{Sağllk kurumlarına başvurma}

Tablo 4'te görülebileceği gibi, örneklemdeki erkeklerin yaklaşık beşte biri sağlık kurumlarına hiç başvurmamaktadır. Kadınların sağlık kurumlarına hiç başvurmama oranları erkeklerinkinden düşük olsa da hem kırsal hem de kentsel alanda sağlık kurumlarına 'biraz hastalanınca' başvuranların oranı erkeklerinkinden düşük, ancak 'çok hastalanınca' başvuranların oranı ise erkeklerinkinden yüksektir. Diğer bir deyişle kadınlar sağlık kurumlarına daha acil durumlarda başvurma eğilimindedirler. Bu durum, kadınların bir kısmının ekonomik kaynaklardan yoksun olduğu için sağlık kurumuna başvuramamasından kaynaklanmaktadır. Örnekleme bir sağllk kuruluşuna başvurmak istediği halde gerekli ekonomik kaynaklardan mahrum olma durumunu deneyimleyip deneyimlemediği sorulmuştur. Tablo 4'te görülebileceği gibi kırsal alanda yaşayan kadınların dörtte üçünden fazlası, kentsel alanda yaşayan kadınların ise yaklaşık üçte ikisi sağlık kurumuna başvurması gerektiği halde ekonomik engellerle karşılaşı̆ı̆ını belirtmiştir ki bu oranlar her iki grupta da erkeklerinkinden yüksektir.

\begin{tabular}{|c|c|c|c|c|}
\hline \multicolumn{5}{|c|}{ Tablo 4: Sağlık kurumlarına bașvurmaya ilișkin değișkenlerin örneklemde dağılımı, \% } \\
\hline & Kirsal & Kentsel & & \\
\hline & Erkek $n=54$ & Kadın $n=49$ & Erkel & \\
\hline \multicolumn{5}{|l|}{$\begin{array}{l}\text { Sağlık kurumlarına } \\
\text { başvurma }\end{array}$} \\
\hline Hiç gitmem & 18 & 6 & 20 & 5 \\
\hline $\begin{array}{l}\text { Çok hastalanınca } \\
\text { giderim }\end{array}$ & 50 & 59 & 51 & 65 \\
\hline $\begin{array}{l}\text { Biraz hastalanınca } \\
\text { giderim }\end{array}$ & 15 & 8 & 9 & 8 \\
\hline $\begin{array}{l}\text { Hasta olmasam da } \\
\text { kontrole giderim }\end{array}$ & 17 & 27 & 20 & 22 \\
\hline Toplam & 100 & 100 & 100 & 100 \\
\hline \multicolumn{5}{|l|}{$\begin{array}{l}\text { Sağlık kurumuna } \\
\text { başvurmada } \\
\text { ekonomik engellerle } \\
\text { karşılaşma }\end{array}$} \\
\hline Evet karşılaştım & 54 & 76 & 38 & 62 \\
\hline Hayır karşılaşmadım & 46 & 24 & 62 & 38 \\
\hline Toplam & 100 & 100 & 100 & 100 \\
\hline
\end{tabular}

Karşılaştıkları ekonomik engeli nasıl aştıkları sorulduğunda örneklem genelinin \%68'i mal satarak ya da borç bularak aştığını belirtmiş, sorunu mal satarak çözenlerin genellikle erkek olduğu, kadınların ise ağırlıklı olarak borç arama yoluna yöneldiği gözlenmiştir. Karşılaştığı ekonomik engeli aşamadığ için sağlık bakımı almaktan vazgeçmek zorunda kalanların büyük çoğunluğu (\%70) kadındır. Hem kırsal hem de kentsel alanda kadınlar erkeklere oranla ekonomik engelleri aşma konusunda dezavantajlıdır. Kırsal alanda yaşayan erkeklerin $\% 17$ 'si, kadınların ise \%22'si sorunu çözemediğini ve bu nedenle sağlık kurumuna başvuramadığını belirtmektedir. Bu oranın her iki grup için de daha yüksek olduğu kentsel alanda ise erkeklerin \%21'i, kadınların \%37'si ekonomik engeli aşamayarak sağlık bakımı aramaktan vazgeçmektedir. Ekonomik engeller nedeniyle sağlık bakımı almaktan vazgeçmek zorunda kalan bazı kadınların ifadeleri aşağıdaki gibidir. 
"Çocukların gönlü olursa veriyor. Yoksa gitmiyorsun. ... bulamadım, evde kaldım o oldu." (kentsel)

"Gitmemekle çözdüm, evde yattım hep." (kırsal)

"Çok oldu, gitmedim mecbur, para olmayınca nereye gidecen." (kirsal)

"Gitmeyiverdik, köyde eyi olduk." (kırsal)

"Bıraktık geldik. Elde avuçta olmayınca n'aapçan?" (kırsal)

"Para bulunca ... giderdik. Yayan gittiğim çok oldu." (kentsel)

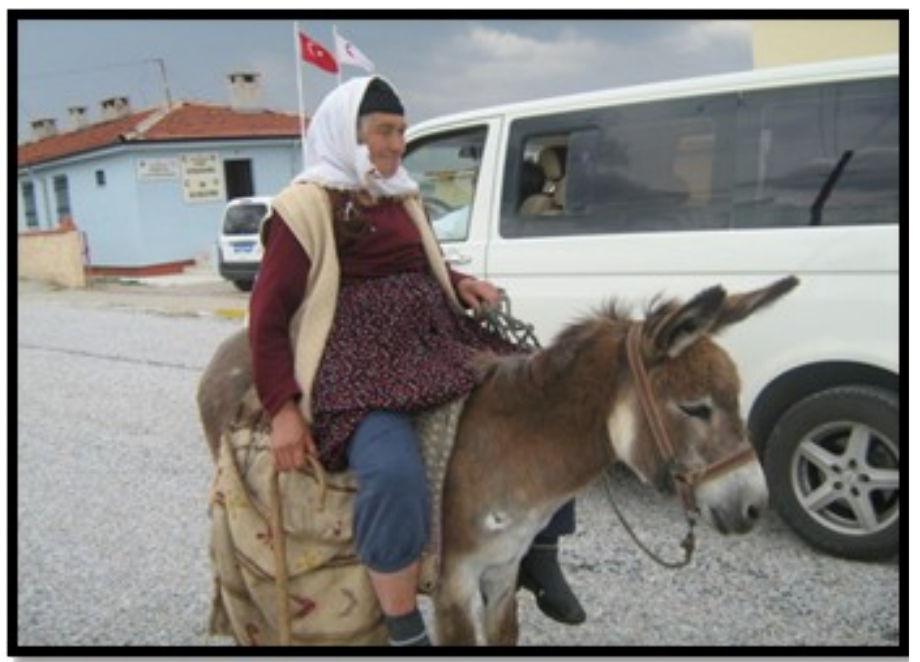

Fotoğraf 2: Kırsal alanda yaşayan kadınlar sağlik kurumlarına başvurmada hem bölgesel, hem ekonomik, hem de ataerkil nedenlerden kaynaklanan zorluklar yaşamaktadır.

Kırsal alanda sağlık hizmetlerinin yetersizliği, kırsal alanda yaşayan kadınların temel sorunlarından biri olarak kabul edilmektedir. ${ }^{44}$ Prim ödemeleri, katkı ve katılım payları kadar ulaşım maliyetleri de ekonomik kaynaklara duyulan gereksinimi artırmaktadır. Ulaşım maliyetlerini karşılayacak ekonomik kaynaklardan yoksunluk, kadınların hangi sağlık kuruluşuna başvuracağını seçerken en çok fiziksel yakınlığa göre seçim yapmasına neden olmaktadır. Kadınların \%40’1 sağlık kurumunu fiziksel yakınlığa göre seçerken bu oran erkeklerde \%28'e gerilemektedir. Kırsal örneklemdeki kadınların yaşadığı üç köyden sadece birinde faal bir yerel sağlık kurumu (sağlık evi) vardır ve köyde yaşayanlar sağlı hizmetlerinden faydalanmak için yakınlardaki kasabalara ya da ilçe merkezlerine ulaşmak zorundadır. Kadınlar bir yandan bu koşullar nedeniyle önemi artan ulaşım maliyetleri, bir yandan da fiziksel hareketliliklerini sınırlayan cinsiyetçi engeller nedeniyle sağlık hizmetlerine erişim açısından dezavantajlıdırlar. Kadınların sağlık kurumlarına başvurmak üzere hanedeki erkeklerden izin ve/veya para istemek zorunda kalmaları ya da tek başlarına gidemedikleri takdirde eşlik edilme isteklerinin erkekler tarafindan

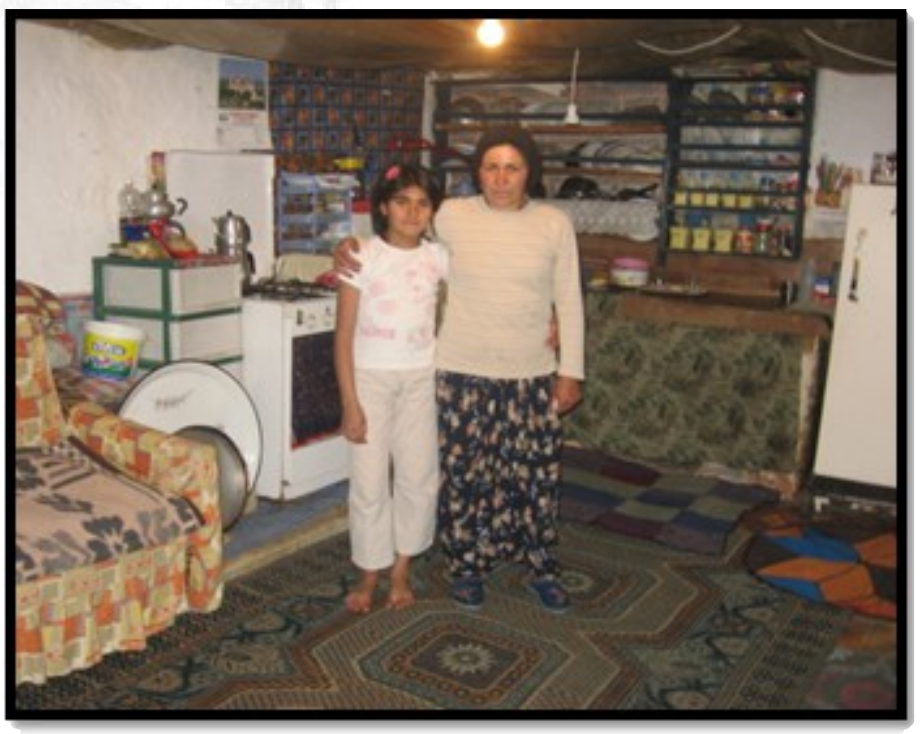

Fotoğraf 3: Kırsal örneklem grubundan bir katılımc1 ve kız1 karşılanmaması, sağlık kurumlarına başvurmalarını zorlaştırmaktadır. Kırsal alanda yaşayan kadınlardan bazıları bu durumu şu şekilde ifade etmektedir:

“...götürmezler ki... komaya girince anca götürürler hastanaya.” 
“...Ben diyom darallyom adam yavu beni bir Çifteler'e [hastaneye] götür zalım eline düşı̈̈̆ümü biliyo götürmüyo."

“Göndermiyorlar, para vermiyorlar, salmıyorlar da evden.”

"Doktor sevk etti, önüme düşüp götüren olmadı gidemedim. Başımda bir erkeğim olmayınca gidemedim."

\section{Săglık Riskleri}

Sağlık açısından önemli bir faktör olan yeterli ve dengeli beslenme de kadınların dezavantajlı olduğu bir konudur. Örneklemin temel besin gruplarındaki yiyecekleri tüketme sıklı̆̆ı incelendiğinde özellikle kentsel alanda yaşayan kadınların et ve et ürünlerini erkeklere oranla belirgin şekilde daha seyrek tükettikleri gözlenmiştir. Hayvansal gıdaların tüketiminin kırsal alandan farklı olarak nakde bağlı olduğu kentsel alanda yaşayan kadınların yarısından fazlası $(\% 53)$ et ve et ürünlerini ayda bir ya da daha seyrek tükettiğini belirtmektedir. Yeterli beslenme ve gelir arasındaki ilişkiyi gözlemlemek için örnekleme ekonomik nedenlerle porsiyon küçültmek / öğün atlamak ve yeterli yemek olmadığı için sofradan aç kalkmak zorunda kalıp kalmadıkları sorulmuştur. Tablo 5'te görülebileceği gibi hem kırsal hem de kentsel alanda kadınların yaklaşık üçte biri haftada bir ya da daha sık olmak üzere ekonomik nedenlere bağlı olarak porsiyonlarını küçülttüklerini ya da öğün atladıklarını belirtirken bu oran erkeklerde neredeyse yarı yarıya düşmektedir. Ekonomik nedenlerle sofradan aç kalkma durumunda farklılık daha da belirgindir, özellikle kırsal alanda kadınların yaklaşık üçte biri haftada bir ya da daha sıklıkla sofradan aç kalkmak zorunda kalırken bu oran erkeklerde \%10'un altındadır. Erkeklere oranla kadınların yetersiz beslenme riskine daha fazla maruz kaldığını gösteren bu bulgular, yetersiz beslenmenin cinsiyetle ilişkili olduğunu, kadınların erkeklere oranla daha yüksek yetersiz beslenme riski altında olduğ $\mathrm{u}^{45}$ bulgularına paraleldir.

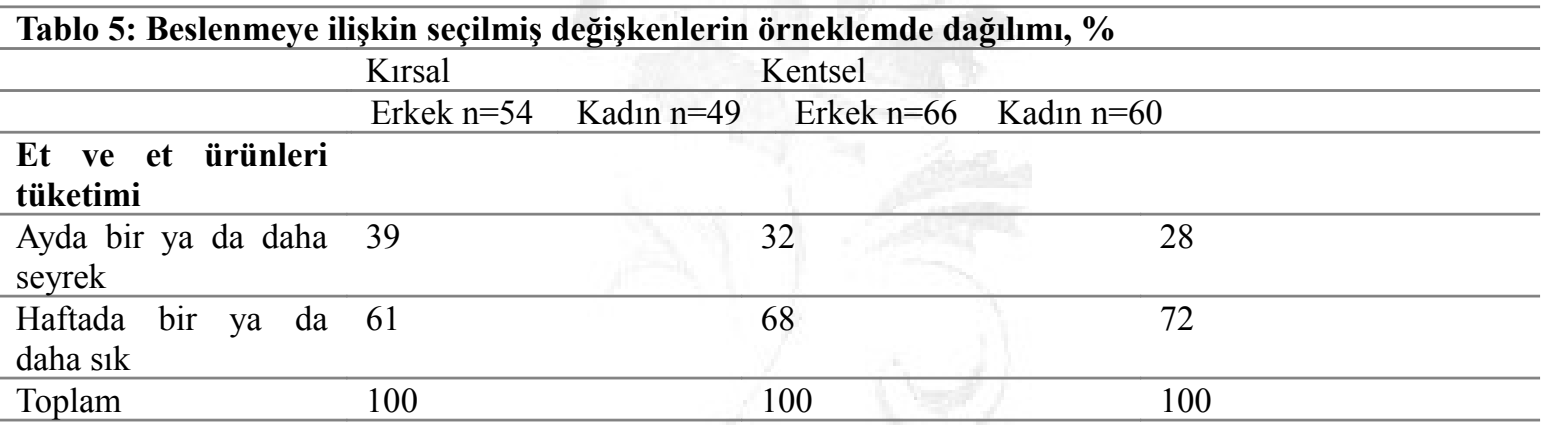

\begin{tabular}{|c|c|c|c|}
\hline $\begin{array}{l}\text { Ekonomik } \\
\text { nedenlerle porsiyon } \\
\text { küçültme }\end{array}$ & & & \\
\hline Hiçbir zaman & 66 & 53 & 62 \\
\hline Birkaç ayda bir & 9 & 4 & 8 \\
\hline Ayda bir & 8 & 12 & 13 \\
\hline $\begin{array}{l}\text { Haftada bir ya da } \\
\text { daha s1k }\end{array}$ & 17 & 31 & 17 \\
\hline Toplam & 100 & 100 & 100 \\
\hline \multicolumn{4}{|l|}{$\begin{array}{l}\text { Ekonomik } \\
\text { nedenlerle sofradan } \\
\text { ac kalkma }\end{array}$} \\
\hline Hiçbir zaman & 83 & 63 & 75 \\
\hline Birkaç ayda bir & 4 & 2 & 8 \\
\hline Ayda bir & 4 & 4 & 9 \\
\hline Haftada bir ya da & 9 & 31 & 8 \\
\hline
\end{tabular}


daha sik

\begin{tabular}{llll}
\hline Toplam & 100 & 100 & 100 \\
\hline
\end{tabular}

Sağlık risklerine karşı alınan önlemlerden biri de son yıllarda giderek yaygınlaşan grip aşısıdır. Örneklemde grip aşısı olanların genel ortalaması düşüktür (\%20), ancak kadınların aşılanma oranı hem kırsal hem de kentsel alanda erkeklerin oranının yarısından azdır. Grip aşısı olma oranı en yüksek düzeyde kırsal alanda yaşayan erkeklerde (\%33), sonra kentsel alanda yaşayan erkeklerde (\%24), ardından kırsal alanda yaşayan kadınlarda (\%16) ve en düşük düzeyde kentsel alanda yaşayan kadınlarda (\%7) görülmektedir.

Kırsal ve kentsel alanda yaşayan kadınların sağlık riskleri ve sağlık statüleri açısından farklılaşmasının nedenlerinden biri de kuşkusuz yaşama koşullarıdır. Örneğin kentsel alanda yaşayan kadınların \%85'inin evinin içinde tuvalet yer alırken kırsal alanda bu oran ancak \%30'dur. Kentsel alanda yaşayan kadınların \%98'inin evinin banyosunda ve tuvaletinde su tesisatı varken kırsal alanda banyoda su tesisatı bulunma oranı \%79, tuvalette su tesisatı bulunma oranı \%69'dur. Kırsal alanda yaşayan kadınların \%67'si içme suyu ihtiyacını doğal bir kaynaktan taşıyarak gidermektedir. Küçük çocuğu olan kadınlardan kentsel alanda yaşayanların \%27'si hazır çocuk bezi kullanmadığını belirtirken bu oran kırsal alanda yaşayan kadınlarda \%35'e yükselmektedir. Kentsel alanda yaşayan kadınların beşte biri hiç tuvalet kâğıdı kullanmadığını belirtirken bu oran kırsal alanda yaşayan kadınlarda \%40'a yükselmektedir. Bu veriler kırsal alanda yaşayan kadınların temizlikle ilişkili sağlık risklerine kentsel alanda yaşayan kadınlardan daha yüksek düzeyde maruz kaldığına işaret etmektedir.

\section{Să̆lık personeline ve să̆lık hizmetlerine yönelik değerlendirme}

Örneklemdeki kadın ve erkeklerin sağlık personelinin davranışlarından memnun olma oranları birbirine yakındır ve kırsal alanda memnuniyet düzeyleri kentsel alana oranla daha yüksektir. Bununla birlikte Tablo 6'da görülebileceği kadınların sağlık hizmeti alırken 'azarlanmaktan' şikâyet etme oranları erkeklerin iki katından fazladır ve kırsal alanda yaşayan kadınların sağlık hizmetlerinin yetersiz olduğunu düşünme oranı erkeklere göre daha yüksektir. Bu bulgular sağlık hizmetlerinin sağlanmasında cinsiyetçi davranışları vurgulayan çalışmaların ${ }^{18}$ görüşlerini desteklemektedir.

Tablo 6: Sağlık personelinin davranışlarına ve sağlık hizmetlerinin yeterliğine ilişkin değişkenlerin örneklemde dağılımı, \%

\begin{tabular}{|c|c|c|c|}
\hline & Kirsal & Kentsel & \\
\hline & Erkek $n=54 \quad$ Kadın $n=49$ & Erkek $\mathrm{n}=66$ & Kadın $n=60$ \\
\hline $\begin{array}{l}\text { Sağlık personelinin } \\
\text { davranışlarından } \\
\text { duyulan } \\
\text { memnuniyet }\end{array}$ & & & \\
\hline Memnun & 78 & 88 & 69 \\
\hline Memnun değil & 22 & 12 & 31 \\
\hline Toplam & 100 & 100 & 100 \\
\hline $\begin{array}{lr}\text { En çok } & \text { rahatsız } \\
\text { olunan } & \text { sağlık } \\
\text { personeli davranışı }\end{array}$ & & & \\
\hline Azarlama & 25 & 57 & 26 \\
\hline İlgisizlik & 12 & 14 & 26 \\
\hline Suratsızlık & 37 & 0 & 10 \\
\hline Diğer & 26 & 29 & 38 \\
\hline Toplam & 100 & 100 & 100 \\
\hline $\begin{array}{l}\text { Sağlık } \\
\text { hizmetlerinin } \\
\text { yeterliliğine ilişkin } \\
\text { düşünce }\end{array}$ & & & \\
\hline Oldukça yeterli & 6 & 6 & 5 \\
\hline Yeterli & 46 & 20 & 33 \\
\hline
\end{tabular}




\begin{tabular}{llll} 
Yetersiz & 37 & 47 & 52 \\
\hline Oldukça yetersiz & 9 & 25 & 8 \\
\hline Fikri yok & 2 & 2 & 2 \\
\hline Toplam & 100 & 100 & 100 \\
\hline
\end{tabular}

\section{Gebelik ve Doğum}

Gebelik ve doğum ile ilgili veriler, bölgesel eşitsizliklerin kadınlar üzerindeki etkisini göstermektedir. Tablo 7'de görülebileceği gibi kırsal alanda yaşayan kadınların gebe kalma ortalamaları kentsel alanda yaşayanların neredeyse iki katıdır ve düşük yapma ortalamaları da kentsel alandan daha yüksektir.

\begin{tabular}{|c|c|}
\hline & Kirsal \\
\hline Doğumun yapıldığı yer & $\mathrm{n}=48$ \\
\hline Evde & 76 \\
\hline Hastanede & 18 \\
\hline $\begin{array}{l}\text { Bazılarını evde bazılarını } \\
\text { hastanede }\end{array}$ & 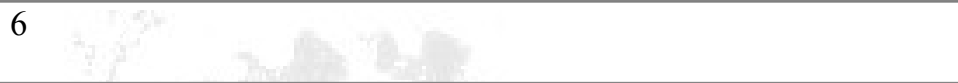 \\
\hline Toplam & 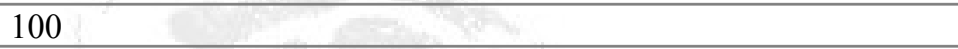 \\
\hline $\begin{array}{l}\text { Evde yapılan doğuma } \\
\text { yardım eden kişi }\end{array}$ & $\mathrm{n}=33$ \\
\hline Ebe & 76 \\
\hline Komşu & 16 \\
\hline Akraba & 1 \\
\hline Hiç kimse & 7 \\
\hline Toplam & 100 \\
\hline Gebelik & $\mathrm{n}=49$ \\
\hline Ortalama & 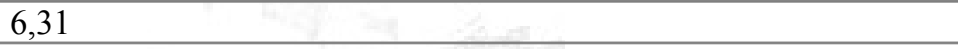 \\
\hline Standart Sapma & 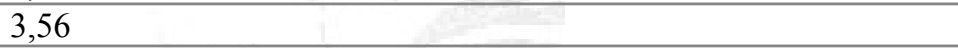 \\
\hline Doğum & 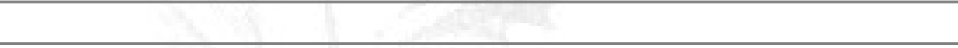 \\
\hline Ortalama & 4,53 \\
\hline Standart Sapma & 2,19 \\
\hline Düşük & 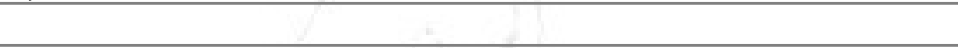 \\
\hline Ortalama & 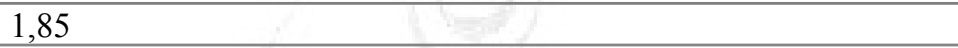 \\
\hline Standart Sapma & 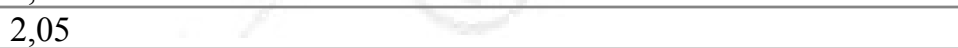 \\
\hline
\end{tabular}

Kentsel alanda yaşayan kadınların dörtte üçüne yakını (\%73) doğumlarını hastanede yaparken bu oran kırsal alanda yaşayan kadınlarda \%18'e gerilemektedir. Evde yapılan doğumlara ağırlıklı olarak ebeler, daha düşük oranlarda komşu ve akrabalar yardım etse de evde doğum yapan kadınlar içinde kırsal alanda yaşayanların $\% 7$ 'si, kentsel alanda yaşayanların ise \%22'si kimseden yardım almadıklarını belirtmiştir. Kimseden yardım almadan evde doğum yapan kadınların ifadelerinden bazıları aşağıdadır.

“Evde kendim. O zaman ebe-doktor yoktu burda." (kursal, 8 gebelik, 1 düşük)

“Evde yaptım, göbek bağını bile kesçek [kimse] yoktu.” (kentsel, 12 gebelik, 4 düşük)

“Evde kendim leğene doğurdum. Normalse [kendin] doğurursun. Ölüyü ebe doğurdu.” (kırsal, 8 gebelik, 1 düşük)

Sağlık Bakanlığı'nın yönergeleri "Gebelik sayısı ne olursa olsun, doğum mutlaka bir să̆lık kuruluşunda gerçekleştirilmelidir. Ancak zorunlu hallerde sağlık personeli yardımı ile evde gerçekleştirilebilir" ${ }^{46}$ ifadesini içermekle beraber araştırmanın bulguları, üreme sağlığı konusunda verilen hizmetlerin nicelik ve niteliği artsa da kültürel faktörler nedeniyle bu konuda çeşitli zorluklar yaşandığını gösteren çalışmalarla ${ }^{47}$ paraleldir. Türkiye 

genelinde doğumu evde yapma ortalaması 2008 itibariyla \%10'dur, bu oran kentsel alanlarda \%5,4'e gerilemekte, kırsal alanlarda ise \%20,4'e yükselmektedir. Yine Türkiye genelinde eğitim ve gelir düzeyi düşük olan kadınların doğumlarını evde yapma oranları istatistiksel bölge ortalamalarının üzerindedir. ${ }^{48}$ Araştırma bulguları da bu eğilimi yansıtmaktadır, örneklemde yaş azaldıkça, eğitim ve gelir düzeyi arttıkça doğumları evde yapma oranı azalmaktadır. 61 yaşın üzerindekilerin \%72'si doğumlarını evde yaptığını belirtirken bu oran 41-60 yaş aralığında \%43'e, 40 yaş altında ise \%14'e gerilemektedir. Doğumu evde yapma oranı okuryazar olmayanlarda $\% 74$, diplomasız okuryazarlarda $\% 69$, ilkokul mezunlarında $\% 51$, ortaokul mezunlarında $\% 6$ ve lise mezunlarında $\% 5$ 'tir. Türkiye genelinin verilerine göre ise eğitimi olmayanlarda \%28,8, ilkokul mezunlarında $\% 6,2$, ortaokul mezunlarında $\% 2,4$, lise ve üzeri mezuniyeti olanlarda ise 0,8 'dir. Şu halde doğumu evde yapma ortalamasını eğitim dışında etkileyen nedenlerin olduğu, örneklemde doğum yapma oranının gelir ve meslek gibi değişkenlerin de etkisiyle arttığı söylenebilir. Nitekim Türkiye genelinde en düşük hanehalkı refah düzeyinde olanların doğumu evde yapma ortalaması \%28,5 iken en yüksek refah düzeyinde olanlarda \%0,9'a gerilemektedir ${ }^{49}$. Örneklemde de aylık hane geliri 500 TL ve altında olanlarda doğumları evde yapma oranı \%62 iken bu oran aylık hane geliri 501-1500 TL arasında olanlarda \%31'e, 1501-2500 TL arasında olanlarda ise \%12'ye gerilemektedir. Türkiye geneli ile araştırma bulguları arasındaki farkın muhtemel nedeni örneklemin genel olarak düşük statü gruplarından, kırsal alanda da özellikle azgelişmiş ilçelerden seçilmiş olması ve Türkiye ortalamalarının daha yüksek statü gruplarını da içermesidir. Diğer bir deyişle gelir, eğitim, meslek ve istihdam statüsü açısından yaşanan dezavantajların kadınlar üzerinde birikimsel bir etkisi vardır. Örneklemde \%76'sı evde doğum yapmış olan kırsal alanda yaşayan kadınların \%94'ünün en fazla ilkokul mezunu olduğu, \%71'inin aylık $500 \mathrm{TL}$ ve altında aylık gelirinin olduğu, \%84'ünün ev dışında ücretli bir işte çalışmadığı dikkate alınmalıdır. Şu halde eğitim ya da gelir gibi değişkenler bağımsız olarak evde doğum yapma oranını artırsa da doğumlarını evde yapanların daha çok ekonomik, eğitimsel ve bölgesel eşitsizlikleri birikimsel olarak deneyimleyen kadınlar olduğu söylenebilir.

Kırsal alanda yaşayan kadınların yarısından fazlası (\%59), kentsel alanda yaşayan kadınların da üçte birinden fazlası (\%35) gebeliği sırasında hiç doktor kontrolüne gitmediğini, kırsal alanda yaşayan kadınların $\% 6$ 'sı ve kentsel alanda yaşayan kadınların \%2'si gebelikleri sırasında doktor kontrolüne gidip gitmediklerini hatırlamadıklarını belirtmektedirler. Kontrole gidenler incelendiğinde bölgesel dezavantajlar belirginleşmektedir. Kırsal alanda yaşayan kadınlar gebelik sırasında ortalama 1,52 (SS=2,75) kere doktor kontrolüne giderken kırsal alanda yaşayan kadınların ortalaması 7,65 ( $\mathrm{SS}=9,32)$ yaklaşık beş kat daha yüksektir. Türkiye genelinde de doğum öncesi sağlık bakım almayanların oranı kırsal alanda $(\% 15,7)$ kentsel alandan $(\% 5)$ daha yüksektir ${ }^{50}$ ancak araştırma bulgularında bu oranlar Türkiye ortalamalarının çok daha üzerindedir. Bu durum, ortalamaları etkileyen merkeze yakın kalabalık ilçe ve köylerin kırsal alanın dezavantajlarını ancak kısmen yansıttığına işaret etmekte ve kırsal alanın merkeze uzak ve azgelişmiş bölgeleriyle ilgili daha fazla veriye ihtiyaç olduğuna işaret etmektedir. Azgelişmiş kırsal alanlarda sağlık hizmeti sağlayan kurumların sayıca azlığı ve fiziksel uzaklığı, kadınların sağlık bakımı almak için tek başlarına başvurmalarının zorluğuna eklenmektedir. Kırsal alanda yaşayan 65 yaş üzerindeki iki kadının aşağıda bulunan ifadelerden görülebileceği gibi, kırsal alanda düşük için bile sağlık kurumlarına başvur(a)mayan kadınlar için gebelik sırasında kontrole gitmek uzak bir ihtimaldir.

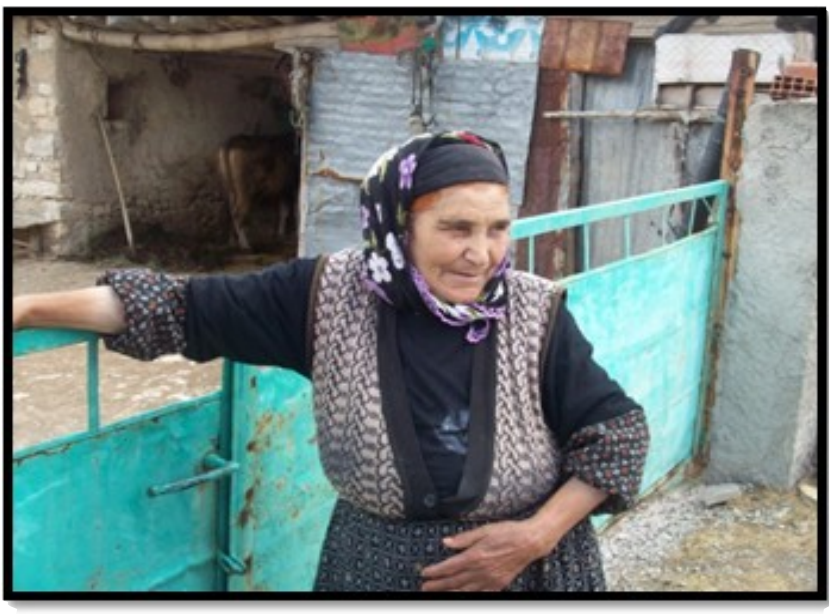

\footnotetext{
"Yooh, daha gebeliği diyon, düşürmek için bile gitmediydik. Deliymişik hekim yok dohtur yok o zamanlar, ne haplar içtik onlar düşsün diye de düşmedi, öleyazdım da komşu kızı kurtard , çekeceğim varmış."

"Nerdee kızım nerde. Gebeliği diyon, hastayken götmez
}

Fotoğraf 4: Kırsal örneklem grubundan bir katılımc1 
dohtora, gebeyken nere götürecek. Sen hastasın bugün bugün bu ev az duruversin demez, bu ev süprülmedi mi der.”

Kırsal alanda daha genç kadınlar için de başka problemler söz konusudur. Aşağıdaki ifade kırsal alanda yaşayan 25 yaşında, iki çocuk sahibi, eşi uzun süredir işsiz olan, eşi ve çocuklarıyla birlikte kayınpederinin evinde (iki kayınbiraderinin evleri ile aynı avluyu paylaşan bir evde) kalan bir kadına aittir. Kadın üçüncü gebeliğinde kürtaj olmak istemiş, kayınpederi para da izin de vermemiş, bunun üzerine tek başına ilçe merkezine gitmiş, bileziklerini bozdurarak kürtaj olmuştur. Bir sonraki gebeliğinde ise kürtaj olacak parası olmadığı için çocuğu dünyaya getirmiş, ancak bakamayacağı için Eskişehir merkezde yaşayan bir çifte evlatlık vermiştir. Aşağıdaki ifadede görülebileceği gibi ekonomik ve ataerkil engeller zaman zaman iç içe geçmektedir.

“...aldırmak istedim, para yok dediler bana. Ben dedim gideyim, izin de vermediler. Kendim gitmeme de izin vermediler yani, o zaman kaçtım ben de. Sabahtan kaçtım, otobüsle ilçeye. Özele gittim, özelde pahalı oldu, 150-160 milyon tuttu, bileziklerimi sattım oldum, döndüm. ... Yine gebe kalınca, bilezik de yok, n'apıcan. ...Halimiz belli... Doğurdum, Eskişehir'e verdim ... evlatlık .... almadım para falan, verdim iște. Nasıl bakacan... ",

Kırsal alanda yaşayan kadınlar yukarıdaki örnekte olduğu gibi doğrudan engellenmeseler bile sağlık hizmetlerine tek başlarına ulaşmada zorluk çekmektedirler. Aşağıdaki ifade kırsal alanda yaşayan, çocuğu olmayan, 76 yaşında, aylık geliri 200 TL olan bir kadına aittir. 31 yaşındayken dört çocuklu bir erkekle evlenmiş, eşi öldükten sonra ameliyat olması gerektiğinde uzun süre kendisiyle kimse ilgilenmediği için ameliyat olamamış, sonunda komşuları tarafindan ilçedeki hastaneye götürülmüştür.

"Kocam kaç kere dövdü beni. Kocam neler yapmadı. Anam verdi beni dayımın oğluna, aman yabancılara gitmesin diye. ... Çocuğum olmayınca üstüme karı aldı kaçtı. 86 yaşında öldü kocam. Bu evin kerpiçlerini ben taşıdım. Kocam beni diri diri yaktı. 50 sene çektim. ... ölüyodum evlerde köşelerde. Kimseye derdimi anlatamadım, ne gelen var ne giden. ... [Hastaneye] El getirdi el götürdü iki gün uyku yüzü görmedim. ... Tarlam takam olsa, yok. Beni kocam beni böyle yaptı. ... Bacaklarım sakat. torbalar dolusu ilaçla yaşıyom. ...et, süt bişi yok. Ekmek yazdırıyom, yazdırılır mı bakkala. ... 1 ekmeği 1 hafta yerim ben. ... Şimdiki aklım olsaydı kız iken evlenmezdim."

\section{Sonuç}

Çalışma, Eskişehir'in kırsal ve kentsel alanlarında yaşayan düşük statülü grupları kapsamaktadır. Bu açıdan bulgulardan eğitim, gelir, meslek ve istihdam statüsü açısından daha avantajlı olan gruplara veya bu grupların da dahil olduğu kent geneline çıkarsama yapılamaz. Bununla birlikte bulgular, kırsal ve kentsel alanda yaşayan düşük statülü kadınların sağlıklarına ilişkin fikir verebilir ve alanda yapılan başka çalışmaların verileriyle birlikte değerlendirildiğinde kadın sağlı̆̆ını etkileyen faktörlere ışık tutabilir.

Bulgular düşük statü gupları içinde kadınların sağlıklarının hem kırsal hem de kentsel alanlarda erkeklerden daha kötü olduğunu, kırsal alanda yaşayan kadınların sağlığının da kentsel alanda yaşayan kadınlara oranla daha kötü olduğunu göstermektedir. Gelir ve eğitim düzeyi gibi sağlığı etkilediği genel olarak kabul edilen değişkenler açısından homojen olan gruplar içinde sağlık açısından kadınların erkeklere göre daha dezavantajlı olması, hem kentsel hem de kırsal alanda yaşayan kadınların sağlığını etkileyen başka değişkenler de olduğuna, kadın sağlığının ekonomik olmayan faktörlerden de etkilendiğine dikkat çekmektedir.

Düşük statülü kadınların sağlıklarının kendileri ile aynı statüdeki erkeklerden daha kötü olmasının bir yandan kadınların ekonomik kaynaklara erişimlerinin sınırlı olmasından diğer yandan da ataerkil yapının yarattığı kısıtlılıklardan kaynaklandığı söylenebilir. Sağlık hizmetlerine erişim için gerekli ulaşım maliyetleri, sigorta primleri, katkı ve katılım payları gibi cepten yapılan ödemeler nedeniyle ekonomik kaynaklara sınırlı erişim kadınların sağlık bakımı almalarını sınırlamaktadır. Ataerkil yapının neden olduğu kültürel engeller ise kadınların beslenme konusunda erkekler ya da çocuklarla eşit önceliğe sahip olmaması, sağlık kurumlarına gitmek üzere hanedeki erkeklerden 'izin' alamamaları ya da tek başına gidemedikleri durumlarda kendilerine eşlik edilmemesi gibi engeller olarak karşımıza çıkabilmektedir. Ataerkil yapıdan kaynaklanan kültürel 
engellerin yanı sıra, sağlık bakımına eriștikten sonra bile kadınlar sağlık personelinin kendilerini 'azarlamasından' erkeklere oranla daha fazla şikâyet etmekte ve sağlık hizmetlerini erkeklere oranla daha yetersiz bulmaktadırlar.

Kadınların sağlığının erkeklerden daha kötü olduğu genel olarak kabul edilmektedir. Ancak bu göstergeyi toplumsal cinsiyeti şekillendiren ekonomik, politik ve kültürel bağlam dışında değerlendirmek, sağlığın biyolojik olmayan belirleyicilerini görmezden gelme ve kadınların yaşadığı dezavantajları basitleştirerek sayısal göstergelere indirgeme riskini taşır. Hâlbuki kadınların sağlık statülerini sistematik olarak kötüleştiren biyolojileri değil, sağlık risklerine daha fazla maruz kalma, sağlık hizmetlerine daha zor erişim, sağlık sigortası kapsamının dışında kalma, cepten yapılan ödemeler nedeniyle sağlık hizmetlerinden yararlanamama ya da sağlık hizmetleri alırken karşılaşılan cinsiyetçi algı ve davranışlar gibi yine toplumsal cinsiyet eşitsizliğinin sonucu olan diğer faktörlerdir. Kadınların sağlığı bir yandan sağlığı doğrudan etkileyen eğitim, gelir ve istihdam gibi sosyoekonomik faktörler açısından dezavantajlı olmalarından, diğer yandan ataerkinin ve cinsiyete dayalı rollerin yarattığı sınırlılıklardan ötürü kötüleşmektedir. $\mathrm{Bu}$ durum sağlık eşitsizliklerinin birikimsel desenini yansıtmaktadır. Özellikle kırsal alandaki kadınların sağlık düzeyleri, ekonomik ve toplumsal cinsiyete dayalı eşitsizliklerle bölgesel eşitsizliklerin kesişmesinin bir izdüşümüdür.

Bulgular iki temel noktaya işaret etmektedir. İlk olarak, kadınların sağlıklarının iyileştirilmesi sağlık sistemine başvurmak zorunda kalmadan, yani 'hasta' olmadan önce yaşadıkları koşulların iyileştirilmesine bağlıdır. "Fiziksel, zihinsel ve toplumsal açılardan tam bir iyilik hali" ${ }^{51}$ olan sağlık, eğitim, meslek, gelir, istihdam ve sosyal statü başta olmak üzere çok sayıda faktör tarafından belirlenmektedir ve kadınların sağlıklarının iyileştirilmesi genel olarak toplumdaki konumlarının iyileşmesine bağlıdır. Bulguların işaret ettiği üzere kadın sağlığı eğitim ve gelir dışındaki faktörler kadar toplumsal cinsiyete dayalı kültürel kısıtlılıklardan da etkilenmektedir. Bu durum toplumsal cinsiyet eşitsizliklerinin kadın sağlığını hem doğrudan hem de dolaylı olarak kötüleştirdiğini, dolayısıyla kadın sağlığının iyileşmesinin kadınların sadece ekonomik değil, toplumsal ve politik açıdan da güçlenmelerine bağlı olduğunu göstermektedir.

İkinci nokta ise, sağlık alanında görülen cinsiyete dayalı eşitsizliklerin giderilebilmesi için kamu hizmeti veren kurumların dezavantajlı gruplara odaklanılacak şekilde yenilenmesi, ${ }^{52}$ diğer bir deyişle sağlık sistemlerinin, politikalarının ve kurumlarının cinsiyet körü olmaktan kaçınılarak toplumsal cinsiyet merkezli bir bakış açısıyla tasarlanması gerekliliğidir. Kadın ve erkeklerin sağlık hizmetlerine yönelik ihtiyaçlarının biyolojik olarak farklılaştığı, ancak bu farklılı̆̆ın yarattı̆̆ taleplerin sağlık sistemleri tarafından adil bir şekilde karşılanmadığı görüşü ${ }^{5354}$ doğru olmakla birlikte kadınlarla erkekler arasındaki farklar biyolojik düzeye indirgenmemeli, sağlık sistemleri ve sağlık politikaları toplumsal cinsiyet merkezli bir şekilde tasarlanmalıdır.

Bulgular ayrıca kadınların doğum öncesi ve doğum sonrası almaları gereken sağlık bakımı konusunda da sorunlar olduğunu göstermektedir. Özellikle kırsal alanda gebelik ve doğum ile ilgili bulguların Türkiye genelinde kırsal alana ilişkin verilerden daha karamsar olması, kırsal alanın homojen olmadığına ve kırsal alanda yaşayan düşük statülü kadınların gebelik ve doğum ile ilgili konularda daha dezavantajlı olduğuna işaret etmektedir. Kadın sağlığının biyolojik yeniden üretim odaklı algılanarak anne sağlığına indirgenmesi kaçınılması gereken bir tutum olmakla birlikte, hem kırsal hem de kentsel alanlarda kadınların gebelik ve doğum sürecinde yeterli sağlık bakımını alabilmeleri için gerekli düzenlemeler yapılmalıdır. Üstelik bu düzenlemeler çerçevesinde ana çocuk sağlığı hizmetlerinin de annenin sağlığını görece ihmal ederek çocuk sağlığına odaklandığ $1^{55}$ eleştirileri dikkate alınmalıdır.

Toplumsal cinsiyet ve sağlık arasındaki ilişki güçlü ve çok boyutlu bir ilişkidir. Kadınların sağlıklarının erkeklerden daha kötü olduğu yönündeki bulgular biyolojik indirgemeciliğe kapılmadan, bu duruma yol açan sağlık eşitsizlikleri ile birlikte değerlendirilmeli ve kadınların daha 'hasta' olduğu vurgusundan kaçınılarak kadın sağlığını kötüleştiren nedenlere odaklanılmalıdır. Diğer bir deyişle kadın sağlığı yalnızca mevcut duruma ilişkin göstergeler üzerinden değil, bu göstergelere neden olan toplumsal güç ilişkileriyle bağlantılı olarak değerlendirilmelidir. Toplumsal cinsiyetin sağlığı ekonomik, toplumsal, politik ve kültürel açılardan etkileme yollarının irdelenmesi ve sağlık eşitsizliklerinin birikimsel deseninin ortaya konması, sağlık eşitsizliklerini azaltacak politikaların geliştirilmesi açısından son derece önemlidir. Kadın sağlığının iyileştirilmesi ve sağlık sistemlerinin toplumsal cinsiyet temelli olarak yeniden tasarlanabilmesi bu politikaların etkin bir şekilde oluşturulmasına ve uygulanmasına bağlıdır. 
'Anke van der Kwaak ve Jashodhara Dasgupta, "Introduction: Gender and Health” içinde: Gender And Health: Policy And Practice: A Global Sourcebook, ed. Anke van der Kwaak ve Madeleen Wegelin-Schuringa (Amsterdam: Oxfam Publishing, 2006), 13-33.

${ }^{2}$ Piroska Östlin, Asha George ve Gita Sen, “Gender, Health, and Equity: The Intersections.” içinde: Challenging Inequalities in Health: From Ethics to Action, ed. Timothy Evans vd. (Oxford: Oxford University Press, 2001), 174-189.

${ }^{3}$ Sarah Wamala ve Gunnar Agren, “Gender Inequity and Public Health: Getting Down to Real Issues," European Journal of Public Health 12 (2002): 163-164

${ }^{4}$ Paula Braveman, "Health disparities and health equity: concepts and measurement," Annual Review of Public Health 27 (2006): 167

${ }^{5}$ Anne Case ve Christina Paxson, “Sex Differences in Morbidity and Mortality,” Demography 42, no.2 (2005):189

${ }^{6}$ Kristina Burström, Magnus Johannesson ve Finn Diderichsen, "Health-related Quality of Life by Disease and Socio-Economic Group in the General Population İn Sweden," Health Policy 55, no.1 (2001): 52

${ }^{7}$ Örjan Hemström, "Health Inequalities by Wage Income in Sweden: The Role of Work Environment," Social Science and Medicine 61, no.3 (2005): 637

${ }^{8}$ Paul A. Bourne ve Desmond Brooks, “Gender, Women and Health: Gendered Health Differences," International Journal of Collaborative Research on Internal Medicine \& Public Health 3, no.7 (2011): 551

${ }^{9}$ Eileen Crimmins, Ki Kim Jung ve Aaron Hagedorn, "Life With and Without Disease: Women Experience More of Both," Journal of Women Aging 14, no1-2, (2002): 56

${ }^{10}$ Omar Rahman vd., “Gender Differences in Adult Health: An International Comparison,” The Gerontologist 34, no.4 (1994): 464

${ }^{11}$ Chloe Bird ve Patricia P. Rieker, "Gender Matters: An Integrated Model for Understanding Men's and Women's Health," Social Science and Medicine 48, no. 6 (1999): 755.

${ }^{12}$ Johan P. Mackenbach vd., "Socioeconomic Inequalities in mortality Among Women and Among Men: An International Study," American Journal of Public Health 89, no.12 (1999):1803

${ }^{13}$ Gita Sen, Asha George ve Piroska Östlin, "Endengering Health Equity: A Review of Research and Policy” içinde: Engendering international health: the challenge of equity, ed. Gita Sen, Asha George ve Piroska Östlin (Cambridge: MIT Press, 2002):3

${ }^{14}$ Ellen Annandale ve Kate Hunt, ed. Gender Inequalities in Health, (Buckingham: Open University Press, 2000): vii

${ }^{15}$ Sarah Payne, The Health of Men and Women (Cambridge: Polity Press, 2006):55

${ }^{16}$ Sara Arber, "Class, Paid Employment and Family Roles: Making Sense of Structural Disadvantage, Gender and Health Status," Social Science and Medicine 32, no.4 (1991):435

${ }^{17}$ Johan P. Mackenbach vd.,1999:1805

${ }^{18}$ Rosaleen O'Brien, Kate Hunt ve Graham J. Hart "It's Caveman Stuff, But That is to a Certain Extent How Guys Still Operate: Men's Accounts of Masculinity and Help Seeking," Social Science and Medicine 61, no.3 (2005): 514

${ }^{19}$ World Health Organization, Gender, Women and Primary Health Care Renewal, Geneva: World Health Organization, 2010):22

${ }^{20}$ Marcel Tanner ve Carol Vlassoff, "Treatment seeking behavior for malaria: a typology based on endemicity and gender," Social Science and Medicine, 46, no.4-5 (1998):526

${ }^{21}$ Guitelle Baghadi, “Gender and Medicines: An International Public Health Perspective,” Journal of Women's Health 14, no.1 (2005): 84

${ }^{22}$ Syed Masud Ahmed vd., "Changing Health-Seeking Behavior in Matlab, Bangladesh: Do Development İnterventions Matter?" Health Policy and Planning 18, no.3 (2003):312 
${ }^{23}$ Marcus Bönte vd, “Women and Men with Coronary Heart Disease İn Three Countries: Are They Treated Differently?” Womens Health Issues 18, no.3 (2008): 197

${ }^{24}$ Piroska Östlin, Asha George ve Gita Sen, 2002:181

${ }^{25}$ Ayşe Akın, “Toplumsal Cinsiyet Ayrımcılı̆̆ı ve Sağlık,” Toplum Hekimliği Bülteni 26,no.2 (2007):4-5

${ }^{26}$ Azer K1lıç, “The Gender Dimension of Social Policy Reform in Turkey: Towards Equal Citizenship?” Social Policy and Administration, 42, no.5 (2008):494

${ }^{27}$ T.C. Sağlık Bakanlığı, Türkiye Ulusal Sağlık Hesapları Hanehalkı Sağlık Harcamaları 2002-2003, (Ankara: T.C. RSHMB, Hıfzıssıhha Mektebi Müdürlüğ̈̈, 2006):25

${ }^{28}$ TUIKK, 2012 Türkiye İstatistik Kurumu Dinamik Sorgulama, http://tuikapp.tuik.gov.tr/isgucuapp/isgucu.zul (erişim: 5 Mart 2013)

${ }^{29}$ Umut Karasu, Eskişehir İl Merkezinde Birinci Basamak Sağlık Kuruluslarında Ruhsal Bozuklukların Yaygınlığı Ve

Sosyodemografik Değişkenlerle İlişkisi. Yayınlanmamış Tıpta Uzmanlık Tezi (Eskişehir: Eskişehir Osmangazi Üniversitesi, 2007):v

${ }^{30}$ TUIKK Sağlık Araştırması (Ankara: TUIK, 2012):5

${ }^{31}$ Paul A.Bourne ve Desmond Brooks, 2011:556

${ }^{32}$ TUİK Sağlık Araştırması (TUiK, 2012):6

${ }^{33}$ Dilek Aslan vd., "What Are the Predictors of Health Services Utilization by Women in a City Center Located in the Eastern Part of Turkey?: A Cross Sectional Study", Turkish Journal of Medical Sciences 36 (2006):37, 42

${ }^{34}$ Hacettepe Üniversitesi Nüfus Etüdleri Enstitüsü, Türkiye Nüfus ve Sağlık Araştırması (TNSA) 2008 (Ankara: Hacettepe Üniversitesi Hastaneleri Basımevi, 2009):150-2

${ }^{35} \mathrm{Bu}$ çalışmada kullanılan verilerin bir kısmı yazarın "Toplumsal Eşitsizlikler ve Sağlık: Eskişehir'de Sosyolojik Bir Araştırma” başlıklı doktora tezinde yer almaktadır.

${ }^{36}$ Bülent Dinçer ve Metin Özaslan, İlçelerin Sosyo-Ekonomik Gelişmişlik Sıralaması Araştırması. Devlet Planlama Teşkilatı Bölgesel Gelişme ve Yapısal Uyum Genel Müdürlüğü. (2004):114 www.dpt.gov.tr/DocObjects/Download/3116/2003-05.pdf Erişim:21.05.2008

${ }^{37}$ Türkiye İstatistik Kurumu Dinamik Sorgulama (2009) (Erişim: 24.05.2009)

${ }^{38}$ Dinçer ve Özaslan, 2004:166

${ }^{39}$ David Goldberg ve Paul Williams. A user's guide to the General Health Questionnaire.(Winsdor: NFER-Nelson, 1988)

${ }^{40}$ P. Gibbons, H.F. De Arevalo ve M. Monico. "Assessment of the factor structure and reliability of the 28 item version of the General Health Questionnaire (GHQ-28) in El Salvador.” International Journal of Clinical and Health Psychology. No.4(2), (2004): 389-398.

${ }^{41}$ Paul A.Bourne ve Desmond Brooks, 2011:557

${ }^{42}$ Maria Del Pilar Sanchez-Lopez, Isabel Cuellar-Flores ve Virginia Dresch, "The Impact of Gender Roles on Health,” Women and Health 52 (2012):187

${ }^{43}$ Ahmad Reza Hosseinpoor vd., "Social Determinants of Self-Reported Health in Women and Men: Understanding the Role of Gender in Population Health,” Plosone 7, no.4 (2012):5

${ }^{44}$ Aşkın Asan vd., Kırsal Alanda Yoksulluğun Gerçek Yüzü: Kadınlar. (Ankara: T.C. Aile ve Sosyal Politikalar Bakanlığı, Strateji Geliştirme Başkanlı̆̆ 1 , (2012):2 
${ }^{45}$ Arijit Nandi vd., "Associations Between Macrolevel Economic Factors and Weight Distributions in Low- and Middle-Income Countries: A Multilevel Analysis of 200000 Adults in 40 Countries," American Journal of Public Health 104, no.2 (2014): 165

${ }^{46}$ T.C. Sağlık Bakanlığı, Gezici Sağlık Hizmetlerinin Yürütülmesi Hakkında Yönerge (Ankara: T.C. Sağlık Bakanlığı, 2006):3

${ }^{47}$ Akın Atauz vd., Türkiye'nin Nüfus ve Kalkınma Yazını: Eleştirel Bir Değerlendirme (Ankara: TÜBA-UNFPA Yayını, 2003):8

${ }^{48}$ Hacettepe Üniversitesi Nüfus Etüdleri Enstitüsü,2009: 150

${ }^{49}$ Hacettepe Üniversitesi Nüfus Etüdleri Enstitüsü,2009:151

${ }^{50}$ Hacettepe Üniversitesi Nüfus Etüdleri Enstitüsü,2009:147

${ }^{51}$ World Health Organization, Official Records of the World Health Organization, no. 2 (1948):100

${ }^{52}$ The World Bank, “Gender Equality and Development,” World Development Report (Washington: The World Bank, 2012 ):23

${ }^{53}$ Gita Sen, Asha George ve Piroska Östlin, 2002:181

${ }^{54}$ Lesley Doyal, Sarah Payne ve Ailsa Cameron, Promoting Gender Equality in Health, (Bristol: Equal Opportunities Commission, 2003):38

${ }^{55}$ Gita Sen, Asha George ve Piroska Östlin, 2002:186.

\section{Kaynakça}

Ahmed, Syed Masud vd., "Changing Health-Seeking Behavior İn Matlab, Bangladesh: Do Development İnterventions Matter?" Health Policy and Planning 18, no.3 (2003):306-315.

Akın, Ayşe. “Toplumsal Cinsiyet Ayrımcılığı ve Sağlık.” Toplum Hekimliği Bülteni 26,no.2 (2007):1-9.

Annandale, Ellen ve Kate Hunt. ed. Gender Inequalities in Health. Buckingham: Open University Press, 2000.

Arber, Sara. "Class, Paid Employment and Family Roles: Making Sense Of Structural Disadvantage, Gender And Health Status.” Social Science and Medicine 32, no.4 (1991):425-436.

Asan, Aşkın vd. Kırsal Alanda Yoksulluğun Gerçek Yüzü: Kadınlar. Ankara: T.C. Aile ve Sosyal Politikalar Bakanlığı, Strateji Geliştirme Başkanlığı, 2012.

Aslan, Dilek vd. "What Are the Predictors of Health Services Utilization by Women in a City Center Located in the Eastern Part of Turkey?: A Cross Sectional Study.", Turkish Journal of Medical Sciences 36 (2006):37-43.

Atauz, Akın vd. Türkiye'nin Nüfus ve Kalkınma Yazını: Eleştirel Bir Değerlendirme. Ankara: TÜBA-UNFPA Yayını, 2003.

Baghadi, Guitelle. “Gender and Medicines: An International Public Health Perspective,” Journal of Women's Health 14, no.1 (2005): 82-86.

Bird, Chloe ve Patricia P. Rieker. “Gender Matters: An Integrated Model for Understanding Men's and Women's Health." Social Science and Medicine 48, no. 6 (1999): 745-755.

Bourne, Paul A. ve Desmond Brooks. "Gender, Women and Health: Gendered Health differences.” International Journal of Collaborative Research on Internal Medicine \& Public Health 3, no.7 (2011): 550-574.

Bönte, Marcus vd. "Women And Men With Coronary Heart Disease in Three Countries: Are They Treated Differently?." Womens Health Issues 18, no.3 (2008): 191-198

Braveman, Paula. "Health Disparities and Health Equity: Concepts and Measurement." Annual Review of Public Health 27 (2006): 167-194.

Burström, Kristina; Johannesson, Magnus ve Finn Diderichsen. (2001). "Health-Related Quality of Life by Disease And Socio-Economic Group in The General Population in Sweden." Health Policy 55, no.1 (2001): 51-69.

Case, Anne ve Christina Paxson. "Sex Differences in Morbidity and Mortality.” Demography 42, no.2 (2005):189-214. 
Crimmins, Eileen; Jung, Ki Kim ve Aaron Hagedorn. "Life With and Without Disease: Women Experience More of Both." Journal of Women Aging 14, no1-2, (2002): 47-59.

Dinçer, Bülent ve Metin Özaslan, İlçelerin Sosyo-Ekonomik Gelişmişlik Sıralaması Araştırması. Devlet Planlama Teşkilatı Bölgesel Gelişme ve Yapısal Uyum Genel Müdürlüğü. (2004) www.dpt.gov.tr/DocObjects/Download/3116/2003-05.pdf Erişim:21.05.2008

Doyal, Lesley; Payne, Sarah ve Ailsa Cameron. Promoting Gender Equality in Health. Bristol: Equal Opportunities Commission, 2003.

Goldberg, D. ve Williams, P. A user's guide to the General Health Questionnaire. Winsdor: NFER-Nelson (1988).

Gibbons, P. H.F. De Arevalo ve M. Monico. "Assessment of the factor structure and reliability of the 28 item version of the General Health Questionnaire (GHQ-28) in El Salvador.” International Journal of Clinical and Health Psychology. No.4(2), (2004): 389-398.

Hacettepe Üniversitesi Nüfus Etüdleri Enstitüsü. Türkiye Nüfus ve Sağlık Araştırması 2008. Ankara: Hacettepe Üniversitesi Hastaneleri Basımevi, 2009.

Hemström, Örjan. "Health Inequalities by Wage Income in Sweden: The Role of Work Environment," Social Science and Medicine 61, no.3 (2005): 637-647.

Hosseinpoor, Ahmad Reza vd. "Social Determinants of Self-Reported Health in Women and Men: Understanding the Role of Gender in Population Health.” Plosone 7, no.4 (2012):1-9.

Karasu, Umut. Eskişehir Il Merkezinde Birinci Basamak Sağlık Kuruluslarında Ruhsal Bozuklukların Yaygınlı̆̆ı Ve Sosyodemografik Değişkenlerle İlişkisi. Yayınlanmamış Tıpta Uzmanlık Tezi, Eskişehir: Eskişehir Osmangazi Üniversitesi, 2007.

Kılıç, Azer. “The Gender Dimension of Social Policy Reform in Turkey: Towards Equal Citizenship?” Social Policy and Administration, 42, no.5 (2008): 487-503.

Mackenbach, Johan P. vd. "Socioeconomic Inequalities in Mortality Among Women and Among Men: An International Study.” American Journal of Public Health 89, no.12 (1999):1800-1806.

Nandi, Arijit vd. “Associations Between Macrolevel Economic Factors and Weight Distributions in Low- and MiddleIncome Countries: A Multilevel Analysis of 200000 Adults in 40 Countries." American Journal of Public Health 104, no.2 (2014): 162-172.

O’Brien, Rosaleen, Hunt, Kate ve Graham J. Hart. "It's Caveman Stuff, But That is to a Certain Extent How Guys Still Operate: Men's Accounts Of Masculinity and Help seeking.” Social Science and Medicine 61, no.3 (2005): 503-516.

Östlin, Piroska, George, Asha ve Gita Sen. “Gender, Health, and Equity: The Intersections.” İçinde: Challenging Inequalities in Health: From Ethics to Action, ed. Timothy Evans vd. 174-189. Oxford: Oxford University Press, 2001.

Payne, Sarah. The Health of Men and Women. Cambridge: Polity Press, 2006.

Rahman, Omar vd., "Gender Differences in Adult Health: an International Comparison.” The Gerontologist 34, no.4 (1994): 463-439.

Sanchez-Lopez, Maria Del Pilar; Cuellar-Flores Isabel ve Virginia Dresch. "The Impact of Gender Roles on Health." Women and Health 52 (2012):182-196.

Sen, Gita; George, Asha ve Piroska Östlin. "Endengering Health Equity: A Review of Research and Policy” İçinde: Engendering International Health: The Challenge Of Equity, ed. Gita Sen, Asha George ve Piroska Östlin, 175-189. Cambridge: MIT Press, 2002.

T.C. Sağlık Bakanlığı, Gezici Sağlık Hizmetlerinin Yürütülmesi Hakkında Yönerge. Ankara:T.C. Sağlık Bakanlığ1, 2006.

T.C. Sağlık Bakanlığı, Türkiye Ulusal Sağlık Hesapları Hanehalkı Sağlık Harcamaları 2002-2003. Ankara: T.C. RSHMB, Hıfzıssıhha Mektebi Müdürlüğü, 2006.

Tanner, Marcel ve Carol Vlassoff. "Treatment Seeking Behavior For Malaria: A Typology Based On Endemicity And Gender.” Social Science and Medicine, 46, no.4-5 (1998): 523-532.

The World Bank, “Gender Equality and Development.” World Development Report. Washington: The World Bank, 2012.

TUİK Sağlık Araştırması, Ankara: TUİK, 2012.

TUİK, 2012 Türkiye İstatistik Kurumu Dinamik Sorgulama, http://tuikapp.tuik.gov.tr/isgucuapp/isgucu.zul (erişim: 5 Mart 2013) 
Van Der Kwaak, Anke ve Dasgupta Jashodhara. "Introduction: Gender and health" İçinde: Gender And Health: Policy And Practice: A Global Sourcebook, ed. Anke van der Kwaak ve Madeleen Wegelin-Schuringa, 13-33. Amsterdam: Oxfam Publishing, 2006.

Wamala, Sarah ve Gunnar Agren. "Gender Inequity and Public Health: Getting Down to Real Issues.” European Journal of Public Health 12 (2002):163-165

World Health Organization. Official Records of the World Health Organization. New York: World Health Organization, 1948.

World Health Organization. Gender, Women And Primary Health Care Renewal. Geneva: World Health Organization, 2010. 